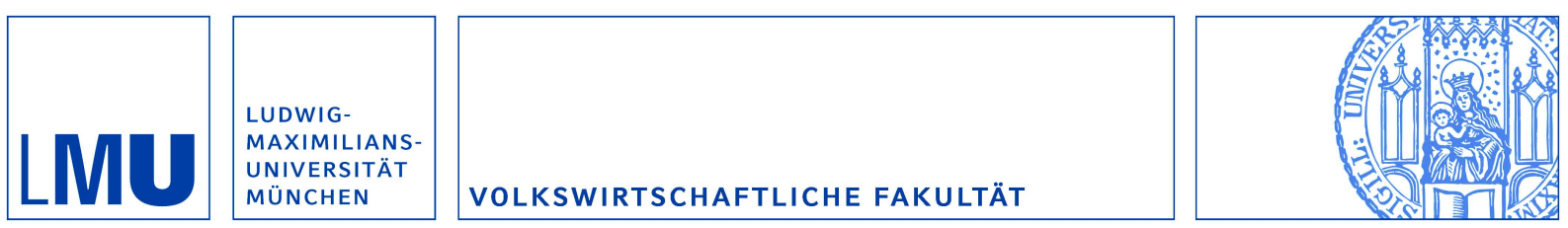

Danzer, Alexander M. und Danzer, Natalia:

The Long-Run Consequences of Chernobyl: Evidence on Subjective Well-Being, Mental Health and Welfare

Munich Discussion Paper No. 2014-25

Department of Economics

University of Munich

Volkswirtschaftliche Fakultät

Ludwig-Maximilians-Universitäł München

Online at https://doi.org/10.5282/ubm/epub.20969 


\title{
The Long-Run Consequences of Chernobyl: Evidence on Subjective Well-Being, Mental Health and Welfare
}

\author{
Alexander M. Danzer \\ Ludwig-Maximilians-University Munich, CESifo Munich, IZA Bonn, IOS Regensburg, \\ Germany, and CReAM, University College London, UK \\ Natalia Danzer \\ Ifo Institute for Economic Research, Munich, and IZA Bonn, Germany
}

June 10, 2014

\begin{abstract}
This paper assesses the long-run toll taken by a large-scale technological disaster on welfare, well-being and mental health. We estimate the causal effect of the 1986 Chernobyl catastrophe after 20 years by linking geographic variation in radioactive fallout to respondents of a nationally representative survey in Ukraine according to their place of residence in 1986. The psychological effects of this nuclear disaster are large and persistent. More affected individuals exhibit poorer subjective well-being, higher depression rates and lower subjective survival probabilities; they rely more on governmental transfers as source of subsistence. We estimate the aggregate annual welfare loss at 6-8\% of Ukraine's GDP highlighting previously ignored externalities of large-scale catastrophes.
\end{abstract}

Keywords: Chernobyl, nuclear catastrophe, externality, subjective well-being, mental health, depression, transfer dependency, welfare loss, natural experiment

JEL codes: I31, I18, D62, Q51, H12

Contact details: Alexander M. Danzer (a.danzer@lmu.de) and Natalia Danzer (danzer@ifo.de).

\$ We thank IZA Bonn, the ULMS consortium and DIW Berlin for sharing the ULMS data with us and Natalia Kharchenko and Volodymyr Paniotto at KIIS for helpful information on the survey and the dataset. We are grateful for helpful and constructive comments by Andrew Clark, Ernst Fehr, Miles Kimball, Stephan Klasen, Lars Handrich, Hartmut Lehmann, Thomas Siedler, Max Steinhardt, Alois Stutzer, Jan Van Ours, Jonathan Wadsworth, and Joachim Winter as well as from conference and seminar participants in Holzhausen, London, Munich, and Sevilla. 
The past 60 years have witnessed 25 serious civic nuclear accidents, the gravest of which were Three Mile Island, Chernobyl and Fukushima. ${ }^{1}$ Such low-probability high-loss events and their consequences represent negative externalities of energy production and use. However, assessing these externalities is complicated as our understanding and conceptualization of the potential societal and economic costs of large-scale disasters are limited and incomplete. On the one hand, technological catastrophes involve direct explicit costs for recovery work, disaster relief, and monetary compensation for victims, which are generally borne by the public as catastrophic events are hardly insurable. On the other hand, such disasters can induce higher order impacts and large implicit costs which have been mostly ignored in conventional economic and risk analyses.

In this paper we evaluate the long-run toll taken by a large-scale technological disaster on individual well-being and mental health as well as on aggregate welfare. To date, these higher order effects have not been assessed in a representative, long-term setup. Our empirical analysis is based on the biggest nuclear accident on record: The Chernobyl disaster of April 26,1986 . It is among the most costly technological accidents and has triggered significant public health concerns. Ukraine's government spending to alleviate the consequences of Chernobyl, including clean-up, recovery work and liquidator ${ }^{2}$ compensation, is estimated at USD 148 billion for 1986-2015 or 5-7\% percent of annual GDP (Oughton, Bay-Larsen, and Voigt 2009). ${ }^{3}$ Most of the early medical research and public attention was drawn to physical health consequences. However, except for the most severely affected clean-up workers and children, researchers could not unambiguously substantiate any adverse physical health effects in the general population (UNSCEAR 2008). Yet, even 20 years after the accident, ordinary Ukrainians, who were affected by low, subclinical radiation doses, report extraordinarily poor subjective health which is in obvious contrast to objective measures (Lehmann and Wadsworth 2011). This divergence between objective and subjective disaster related morbidity hints at psychological effects. In particular, humans dread disasters involving toxic exposure for their catastrophic and uncontrollable potential health impacts and

\footnotetext{
${ }^{1}$ These are according to the International Nuclear Event Scale 4-7: Chalk River 1952 (USA), Kyshtym 1957 (USSR), Sellafield 1957, 1973 (UK), Los Alamos 1958 (USA), Simi Valley 1959 (USA), Idaho Falls 1961 (USA), Charlestown 1964 (USA), Monroe 1966 (USA), Lucens 1969 (Switzerland), Rocky Flats 1969 (USA), Leningrad 1974 (USSR), Belojarsk 1977 (USSR), Bohunice 1977 (CSSR), Three Mile Island 1979 (USA), Saint-Laurent 1980 (France), Chernobyl 1982, 1986 (USSR, nowadays Ukraine), Buenos Aires 1983 (Argentina), Wladiwostok 1985 (USSR), Goiânia 1987 (Brazil), Sewersk 1993 (Russia), Tokaimura 1999 (Japan), Fleurus 2006 (Belgium), and Fukushima 2011 (Japan).

${ }^{2}$ The clean-up workers assigned to deal with consequences of the Chernobyl disaster were called liquidators.

${ }^{3}$ The direct costs associated with the Three Mile Island (1979) accident range between 1-3 billion USD for the first decade (Faure and Skogh 1992).
} 
for their contamination which is undetectable by human senses (Slovic 1987). Psychologists suggest that anxieties in the aftermath of nuclear accidents may have adverse mental health consequences (Bromet, Havenaar and Guey 2011). This is highly relevant for public policy as reduced mental health in general and depression in particular are among the most important determinants of mortality, reduced productivity and low quality of life (European Commission 2004; WHO 2005). ${ }^{4}$ Epidemiological and psychological studies on the most severely affected subgroups of the Chernobyl disaster such as liquidators or evacuees reveal significant mental health impairments. This is in line with short and medium run evidence on elevated levels of mental distress following the nuclear accidents in Three Mile Island and Fukushima (Bromet 2012; Shigemura et al. 2012). However, without a proper long-term assessment of mental health effects in the general population the resulting aggregate welfare loss is unknown and the appraisal of nuclear accidents for public policy remains incomplete.

This paper provides the first empirical assessment of the psychological long-term implications of the Chernobyl catastrophe for the lives of the vast majority of Ukrainians for whom the disaster was-technically speaking - a low-exposure catastrophe. For the general population, the additional annual radiation dose hardly exceeds one annual dose of natural background radiation (comparable to several medical x-rays). Our paper makes three contributions: First, we exploit the natural experiment implied by the random variation in radioactive fallout to establish the causal link between the Chernobyl disaster and its impact on individual mental well-being. We match geographic variation in post-accident radiation doses of iodine-131 and caesium-137 with large-scale, representative survey data containing information on individual place of residence in the year of the disaster. Mental well-being is measured 20 years after the catastrophe with indicators on life satisfaction, diagnosed depressions and subjective survival probabilities. Second, by focusing on long-term mental health outcomes we dissect a previously ignored welfare component of catastrophes. We compute the monetary equivalent of the aggregate welfare loss using the life satisfaction approach which is based on an additive social welfare function. This method has been widely used in the economics literature to evaluate the compensating differential for negative life events or environmental conditions (e.g., Clark and Oswald 2002; Frey, Lüchinger and Stutzer 2010; Levinson 2012; Lüchinger 2009; Lüchinger and Raschky 2009; van Praag and Baarsma 2005; Winkelmann and Winkelmann 1998). It is important to note that our research

\footnotetext{
${ }^{4}$ For instance, to foster awareness for mental disorders and improve mental health care around the globe the WHO set up a Mental Health Action Plan (WHO World Mental Health Survey Consortium 2004).
} 
differs from the literature on the negative "news effect" of catastrophes on subjective wellbeing, which tends to measure transitory short term distress (e.g., Berger 2010; Kimball et al. 2006; Metcalfe, Powdthavee and Dolan 2011). Third, we complement the welfare analysis by highlighting another possible externality of the disaster, namely the greater reliance of individuals on government transfers as a source of livelihood.

Our results indicate, first, that having been exposed to Chernobyl has a significant and considerable negative effect on subjective well-being and mental health even 20 years after the disaster. According to our estimates, one additional dose of natural background radiation leads to a reduction of subjective well-being by $20 \%$ of a standard deviation. This result proves robust to several sensitivity checks and the use of an objective depression indicator. Our findings on significantly reduced subjective survival probabilities furthermore suggest that worries about future individual health are one possible transmission channel through which the catastrophe impacted mental well-being. Second, the annual aggregate welfare loss for the general Ukrainian population equals $6.3-8.4 \%$ of contemporary Ukrainian GDP. These numbers even slightly exceed Ukraine's current annual recovery, clean-up, and liquidator compensation costs of about 5-7\% of GDP. Third, Chernobyl indeed increases the reliance on the state as provider of subsistence. Affected working-age adults are more dependent on governmental social transfers; the fiscal equivalent of these additional benefits amounts to $0.5-0.6 \%$ of annual GDP.

Our findings have important implications for public policy: The psychological effects of a nuclear catastrophe are large and persistent, even for the average population which was exposed to extremely low, subclinical radiation doses. This matters because mental health is crucial not only for personal well-being and public health but also for productivity and economic growth (WHO 2013). Furthermore, the overall welfare loss is substantial and must be interpreted as an externality of nuclear electricity production. The explicit and implicit costs of large nuclear accidents can easily exceed the fiscal latitude of single states.

The remainder of the paper is as follows. Section 1 provides background information on the Chernobyl disaster and its consequences. Section 2 describes and discusses the identification strategy, the data sets as well as the methodological approach. This is followed by the empirical results for different mental well-being measures and one potential transmission channel in Section 3. This section also contains a discussion of the findings and further evidence on behavioural implications. Section 4 presents the monetary evaluation of the aggregate welfare loss caused by Chernobyl. Section 5 concludes. 


\section{Background}

\subsection{The Chernobyl Accident and its Consequences}

The meltdown and explosion of reactor 4 of the nuclear power plant in Chernobyl on April 26, 1986 (located in northern Ukraine) resulted in the biggest civil nuclear accident on record. ${ }^{5}$ The released radioactive matter formed a cloud that contaminated substantial areas of Belarus, Ukraine, and western Russia with radioiodine-131 and radiocaesium-137. In Ukraine, local wind direction, rainfall patterns as well as surface structure scattered radioactive fallout across tens of thousands of square kilometres, leading to regionally dispersed and unpredictable contamination levels (Fig. A-1 in the Appendix). Due to atypically strong eastern winds, vast areas of western and northern Europe were affected, too. The Chernobyl catastrophe was an exogenous and unanticipated event that impacted the population in a non-selective manner. Contamination was not a monotonic function of distance to the damaged power plant (Lehmann and Wadsworth 2011). These particular features of the Chernobyl disaster form the basis for the identification strategy of this paper.

In the vicinity of the reactor, where radioactive exposure was the most extreme, firefighters, military personnel and recovery operations workers (so-called liquidators) tried to curtail the disaster ${ }^{6}$; several thousand people living in the reactor's immediate neighbourhood were evacuated days after the accident and more than 100,000 residents were resettled from inside a 30-kilometer zone of alienation in the following months. The humanitarian consequences of the disaster have been fiercely debated: While the official death toll is 'only' 30 (UNSCEAR 2008), several hundred thousand people were exposed to high radiation doses of 175 to 3000 times the average natural background radiation (350-6000 millisievert, $\mathrm{mSv}$ ) in the vicinity of the reactor. ${ }^{7}$ According to the United Nations Scientific Committee on the Effects of Atomic Radiation (UNSCEAR), the number of persons seriously affected by Chernobyl up to the year 1989 amounted to 1.6 million (UNSCEAR 2000). As clean-up works were and are still ongoing, these numbers were rising over time (UNSCEAR 2008). By January 2004, the number of Ukrainian adults officially recognized as Chernobyl victims

\footnotetext{
${ }^{5}$ More detailed accounts of the timeline of the events as well as technical details can be found in the 1998 European Commission Atlas of caesium deposition on Europe after the Chernobyl accident (European Commission 1998), two United Nations reports from 2001 and 2002 (United Nations 2001, 2002), and two UNSCEAR reports from 2000 and 2008 (UNSCEAR 2000, 2008), as well as in a national report from Ukraine (Baloga, Kholosha, and Evdin 2006).

${ }^{6}$ Military personnel and liquidators were deployed from various parts of the Soviet Union.

${ }^{7}$ Estimates of the expected long-run death toll vary vastly between 4,000 (IAEA 2006) and almost 200,000 (Greenpeace 2006). This huge variance reflects and produces uncertainty about actual health effects.
} 
(implying a special social benefit) exceeded 2 million, corresponding to about $4 \%$ of the Ukrainian population (State Statistics Committee of Ukraine 2004).

It is this particular highly affected subgroup on which most of the medical literature has focused to date. Despite the unprecedented scale of the disaster, it has proven difficult to identify causal physical health effects in adults, e.g., leukaemia, and the existing evidence remains mixed and inconclusive. ${ }^{8}$ In contrast, scientists agree that Chernobyl is responsible for significant increases in the prevalence of thyroid cancer in highly affected children (Demidchik et al. 1999; UNSCEAR 2000). Similarly, there is consensus about the mental health consequences for the most severely affected: Epidemiological and psychological studies show poor mental health among clean-up workers (Ivanov et al. 2001; Loganovsky et al. 2008), those still residing in highly affected areas (Viinamäki et al. 1995; Havenaar et al. 1997) and among those resettled by the government (United Nations 2002). Symptoms attributed to the accident include headache, depression, and sleep disturbance (UNSCEAR 2000). Self-abandonment, feelings of helplessness and lethargy have been described as mental reactions to uncertainty about own health status and the worries about suffering from cancer in the future (United Nations 2002). Suicide rates were significantly higher in the seriously contaminated population (Bromet and Havenaar 2007). ${ }^{9}$

\subsection{Uncertainty and Anxiety in the General Population}

In contrast to the highly affected population, the radiation doses received by the general population were low, comparable to half the annual level of background radiation or 10 chest $x$-ray scans per year. We focus on this under-researched vast majority (96\%) of the general Ukrainian population. The state-of-the-art medical literature is explicit that the low doses of ionizing radiation received by the general population are subclinical, i.e., they neither cause a physical health deterioration nor neurological damage (UNSCEAR 2000; 2008). ${ }^{10}$ Yet, several small-scale and qualitative studies suggest that the general population is scared of radiation and attributes a variety of health conditions to radioactive contamination (Lee 1996;

\footnotetext{
${ }^{8}$ For instance, it is uncertain, to what extent increased cancer rates should be attributed to intensified health screening efforts in the aftermath of the catastrophe (United Nations 2002).

${ }^{9}$ Note that Ukraine underwent serious economic restructuring and transition challenges after the breakdown of the Soviet Union. These shocks may have affected some of our outcome measures. However, the transition shocks were common to everybody, irrespective of exposure to Chernobyl.

${ }^{10}$ Different from previous assumptions, the U.S. National Academy of Sciences BEIR VII Committee (2006) now argues that the cancer risk may actually increase linearly, without threshold in radiation exposure. Strictly speaking, this implies the theoretical possibility that very low doses do affect the cancer rate, albeit at undetectable levels.
} 
UNSCEAR 2000). In line with the contradiction between the objective findings on physical health and the subjective perception of the general population, Lehmann and Wadsworth (2011) estimate negative long-term effects of radiation exposure on subjective health, but no significant objective physical health effects (in a nationally representative survey).

Where could the described anxiety and health worries of people affected by low, subclinical radiation doses come from? After the accident, two mutually re-enforcing sources of uncertainty regarding potential health consequences put the population under distress: First, individuals were uncertain about their treatment state, i.e. their personal level of affectedness, as radiation is invisible, taste- and odourless. However, the Soviet government initiated largescale countermeasures intended to protect residents from radiation. These countermeasures were geographically highly correlated with actual radioactive fallout and have signaled the spatial variation in contamination to the general population. Individuals who actually received very low radiation levels have as a consequence interpreted the official security measures as a signal for serious radiation and health danger (Lee 1996: 301; UNSCEAR 2008). Second, the potential health consequences of the treatment were perceived as highly uncertain. This perception was triggered, on the one hand, by the distinctive features of nuclear radiation and, on the other hand, by the unavailability of reliable information regarding expected health consequences of radiation. Nuclear radiation is often considered slow poison and its consequences may remain latent for long periods of time. Hence, it is uncertain whether and when its consequences will be realized. The unresolved and sometimes ideologically motivated scientific debate on long-term health outcomes, especially with respect to cancer in adults, fostered the uncertainty in the general population. Additionally, the Soviet government deliberately concealed the scale and danger of the accident in 1986, which must have seemed at odds with the series of large scale countermeasures ${ }^{11}$. These contradictory signals created room for rumors and fear which further increased the perceived uncertainty in the population (Bromet 2012; Rahu 2003). Recent research on the role of risk communication in the aftermath of large-scale nuclear accidents seems to confirm that information can serve as a signal about affectedness. In fact, as shown for the accident of Fukushima in 2011, less credible information and greater uncertainty about the consequences of the disaster led to elevated levels of distress in Japan (Rubin et al. 2012).

\footnotetext{
${ }^{11}$ See Chapter 1 in Baloga, Kholosha, and Evdin (2006).
} 
The most salient affectedness signals received by ordinary citizens were the distribution of 5.5 million doses of Potassium Iodide prophylaxis to saturate the thyroid gland with non-hazardous iodide (Mettler et al. 1992), the introduction of a compulsory Chernobyl registry in mid-1986 involving annual medical examinations across the more affected areas (UNSCEAR 2000: 490), the collection of several hundred thousand thyroid measurements and blood tests which had much better coverage in more affected areas (Likhtarev et al., 1994), the setting up of several international medical projects with (partly mobile) cancer screening facilities between 1986 and $1996^{12}$ which gave rise to rumours about disastrous health consequences (Baloga, Kholosha, and Evdin 2006; Gould 1990), and, finally, the widespread screening measures for locally (and even privately) produced food, milk and dairy products as vast tracts of land became unusable for agricultural production (Firsakova, 1993; Likhtarev et al., 1994; UNSCEAR 2008: 74). ${ }^{13}$

As a result, even physically healthy individuals are often afraid of cancer or genetic defects in their children as demonstrated by qualitative interviews in 2003 (Abbott, Wallace, and Beck 2006). Low-dose recipients report elevated levels of stress, anxiety, and medically unexplained physical symptoms (WHO 2006). ${ }^{14}$

\section{Methodology and Data}

\subsection{Identification Strategy}

This paper exploits regional variation in radioactive fallout levels to study the effect of a large-scale catastrophe on long-term mental well-being and behavioral outcomes. We use a representative survey of the Ukrainian population and focus on the $96 \%$ of the general population that was randomly affected by different levels of subclinical radiation doses and that was neither resettled nor involved in disaster liquidation. It is important to stress that we do not interpret our findings on mental well-being as causal effects of radioactive contamination itself. Rather, we argue that our estimates represent significant psychological

\footnotetext{
12 The Chernobyl project (1990-1), the IPHECA project (1992-5) and the Chernobyl Sasakawa Health and Medical Cooperation Project (1991-6).

${ }^{13}$ The contaminated area in Belarus, Ukraine, and Russia totalled 784,000 ha of agricultural land and 694,000 ha of forest (United Nations 2002), equivalent to the size of Kuwait and larger than the state of Connecticut.

14 These negative psychological consequences of the subclinical radiation disaster share features of a psychogenic nocebo effect described in the medical literature (Mitsikostas, Mantonakis and Chalarakis 2014).
} 
long-term disaster effects: the population received information signals about their likely treatment status from countermeasures which had been taken by the authorities in order to prevent the absorption of radiation. The intensity of these countermeasures and signals was regionally highly correlated with actual radioactive fallout.

Undoubtedly, the Chernobyl catastrophe was an unanticipated accident and created an unexpected pattern of regional radiation levels due to unforeseen weather and wind conditions. However, for the regional variation to serve as a valid quasi-experiment, we need to be sure that radiation levels are not correlated with possibly confounding differences in the regional characteristics of the population. One possible confounding effect could be selection into treatment created through endogenous location choice of individuals and families in 1986, that is, if certain types were more likely to live in close proximity to potentially harmful sources like nuclear power plants. ${ }^{15} \mathrm{We}$ argue that this possibility does not apply in our set up: Since the risks of the civil use of nuclear power were generally less well understood at that time, the population's settlement choices were unlikely to be endogenous. More importantly, residential mobility was severely restricted in the Soviet Union, ${ }^{16}$ a country particularly secretive about strategically important sites. Furthermore, contamination was not a monotonic function of distance to Chernobyl (Lehmann and Wadsworth 2011).

Another possible threat to the identification strategy could be endogenous radiation exposure through selection into clean-up work and possibly selected mortality. Indeed, although the deployed liquidation workers were not volunteers, they might differ from the general population as they were predominantly drawn from military, emergency and technical occupations. These workers were exposed to high—some of them to lethal—doses of external radiation and received special medical treatment and attention (e.g., in the form of welfare supplements) (Lehmann and Wadsworth 2011). To account for this problem, we exclude from our sample all evacuees from within the $30-\mathrm{km}$ exclusion zone and later-resettled populations as well as all persons involved in the recovery works. ${ }^{17}$ Hence, our analysis will provide conservative estimates, probably underestimating the (mental) health costs of the disaster.

\footnotetext{
${ }^{15}$ In our sensitivity analysis, we control for living nearby an active nuclear power plant. As of 1986, there were four active nuclear power plants in Ukraine, which were scattered across the country: Rivne (North-West), South Ukraine (South), Zaporizhzhia (East) and Chernobyl (North). A new plant (Khmelnitsky, Centre-West) opened in 1987, while all Chernobyl reactors were finally shut down by the time of the ULMS interviews.

${ }^{16}$ Individuals' labour market choices and mobility were limited due to the internal passport system as well as to the administrative allocation of housing during the Soviet Union (Gregory and Kohlhase 1988).

${ }^{17}$ Our data set contains indicators on whether individuals took part in the liquidation process $(1.6 \%)$ or were evacuated or resettled due to the Chernobyl catastrophe (1.2\%).
} 
Finally, our identification strategy would be jeopardized if regions which incidentally received more radioactive fallout in 1986 were structurally different from less affected regions before the accident. Yet, in a series of individual and regional level regressions we show that there were no significant differences between more and less affected areas with respect to pre-determined characteristics such as educational attainments, employment rates, wages, wage growth, or emigration rates (see Appendix, Tables A-1 and A-2). ${ }^{18}$

\subsection{Data and Main Variables}

Our estimation of the long-term effects of the Chernobyl catastrophe makes use of the Ukrainian Longitudinal Monitoring Survey (ULMS), a rich nationally representative panel data set. These data are unique in providing, on the one hand, information on mental wellbeing 20 years after the accident and, on the other hand, retrospective information on place of residence at the time of the accident as well as on individual-level involvement in clean-up work and resettlement. The panel survey was carried out in the summer months of 2003, 2004, and 2007 by the Kiev International Institute of Sociology (KIIS) and included more than 6,000 adults aged 15 to 75 (Lehmann, Muravyev and Zimmermann 2012). The survey contains an individual questionnaire on socio-demographic characteristics, labour force participation, subjective well-being, attitudes, and health status, as well as a household questionnaire focusing on household composition, income, and housing. A pivotal feature of the ULMS is its collection of retrospective labour market and residential history starting in 1986-the year of the Chernobyl catastrophe. Although recall periods are long, the retrospective information is considered reliable due to the fact that the survey employed memory-anchor techniques and exploited information registered in official Soviet work books whenever available. Exact location of respondents' place of residence in 1986 is crucial for mapping nuclear radiation doses to individuals. We restrict the sample to individuals born before April 26, 1986-this excludes children in utero during the accident, since Almond, Edlund, and Palme (2009) demonstrate that prenatal exposure was potentially harmful. ${ }^{19,20}$

\footnotetext{
${ }^{18}$ Unfortunately, there are no pre-1986 data sets containing subjective/mental well-being and regional indicators for the Ukrainian Soviet Socialist Republic. When assessing the cross-regional mobility patterns of the nonresettled low-dose population between 1986 and 2003 with the ULMS data, we find no significant correlation between the average radiation dose and subsequent outward mobility of a region. Hence, low radiation doses seem not to have induced sorting across regions. Furthermore, less than $1 \%$ of those who changed residence between 1986 and 2003 related the move to the Chernobyl catastrophe (according to the detailed ULMS migration module).

${ }^{19}$ Our results are robust to including children in utero at the time of the catastrophe (results not shown).

${ }^{20}$ Similarly, negative effects of in utero exposure to low-dose nuclear radiation are also found by Black, Bütikofer, Devereux and Salvanes (2013) for Norway as well as Halla and Zweimüller (2014) for Austria.
} 
After excluding the potentially selectively assigned clean-up workers and the resettled population, the final sample is comprised of 11,922 person-year observations.

We additionally exploit another large Ukrainian micro data set containing information on diagnosed mental health conditions: the Ukrainian Household Budget Survey (UHBS), conducted by the Ukrainian Statistical Committee. This annual cross-sectional survey collects household- and individual-level information for around 24,000 individuals in about 9,500 households in December of each year. Mental health (i.e., mental disorder diagnosed by a physician) was covered in the years 2004 to 2006, yielding a sample size of more than 44,000 observations for the analysis. The drawback of the UHBS data is that they lack information on place of residence as of the year 1986 and that we have to assign radiation doses to current place of residence. To address this problem in the UHBS analyses, we reweigh the radiation doses by the inter-regional migration matrix between 1986 and 2003 and additionally control for the inter-regional mobility over the same time period. ${ }^{21}$ To assure comparability between the two data sets, we restrict the UHBS sample to respondents born before the accident and not older than 75 years at the time of the interview. ${ }^{22}$

\subsubsection{Measures of the Disaster Effect}

To measure the impact of the disaster, we use official regional radiation data that we match to individuals based on their place of residence in the year $1986 .{ }^{23}$ We focus on average effective total exposure doses of caesium-137, reflecting the energy absorbed by matter (measured in millisieverts, $\mathrm{mSv}$ ). This is the preferred measure for gauging any long-term (biological) impact, since it allows combining internal (through ingestion and inhalation) and external (fallout) radiation doses. These tend to differ in relative importance across regions, especially since household farming was an important source of subsistence in the Soviet Union (Baloga, Kholosha, and Evdin 2006). As stated above, the received doses in our study population are low and amount on average to one $\mathrm{mSv}$ for May-December of the year 1986 .

\footnotetext{
${ }^{21}$ The formula is Radiation $_{k}=\sum m_{j 8603} \times$ Radiation $_{j 86}$, with $m$ denoting the 2003 population fraction of region $k$ originating from region $j$ as of the year 1986. The full inter-regional migration matrix is based on official migration data from the State Statistics Committee of Ukraine.

${ }^{22}$ As in the ULMS, we also exclude the most severely affected individuals. After applying these sample restrictions, the two datasets are very similar with respect to standard socio-economic characteristics.

${ }^{23}$ This procedure has been also carried out by Lehmann and Wadsworth (2011). However, in contrast to us, they assign a measure of surface contamination with caesium-137 measured in kilobequerels per square meter $(\mathrm{kBq} / \mathrm{sqm})$ to each individual. Furthermore, individuals who did not live on Ukrainian territory in 1986 (4.5\% of the sample) were assigned zero exposure doses (none of these individuals originated from affected areas of Belarus or Russia). The results are robust to either assigning the minimum radiation value of the sample or omitting these observations (results not reported).
} 
This equals half the natural annual background radiation. As additional radiation measure for children, we use regional average exposure to iodine-131. Children and adolescents have been especially vulnerable to this radioactive isotope (owing to common iodine deficiencies) and were subsequently more prone to suffer from thyroid cancer. ${ }^{24}$ Hence, affected children might suffer from an increased perceived risk or worries about future illness. Among the most affected children in our sample, the iodine-131 doses (measured in milligray, mGy) were the equivalent of about 100 abdominal $\mathrm{x}$-rays for adults. ${ }^{25}$

We use official measures on regional averages in radiation exposure provided in Baloga, Kolosha and Evdin (2006). ${ }^{26}$ The radiation data stem from measurements at various locations and are then averaged and extrapolated to larger areas (610 districts with on average 75,000 inhabitants). Specifically, caesium-137 estimates are based on 30,000 white blood cell (WBC) measurements in 1986 across rural and urban locations in Ukraine. Average regional absorbed thyroid doses are estimated based on 150,000 direct measurements of radioiodine activity in the thyroid gland of individuals living in contaminated regions (Baloga, Kholosha, and Evdin 2006). The resulting regional radiation measure is relatively crude and might hide substantial intraregional variation.

\subsubsection{Mental well-being indicators}

The main dependent variable in our assessment of the impact of Chernobyl on individual mental well-being is general life satisfaction. While economic studies interpret subjective well-being as a proxy for utility or welfare (see, e.g., Clark, Frijters and Shields 2008), medical psychologists understand it as affective construct that can be used to assess mental health in general (Headey, Kelley and Wearing 1993) or as indicator for clinical depression in particular (Gargiulo and Stokes 2009). This subjective well-being indicator is measured on a five-point Likert scale from fully dissatisfied (1) to fully satisfied (5) and is based on the ULMS question: "To what extent are you satisfied with your life in general at the present time?" The mean level of life satisfaction is 2.59 (with a standard deviation of 1.16). A first glance at the data reveals that individuals who resided in areas exposed to above median radiation report lower levels of life satisfaction (Fig. 1).

\footnotetext{
${ }^{24}$ While caesium-137 has a relatively long half-life of 30.8 years, iodine-131 has a half-life of about eight days.

${ }^{25}$ Milligray is a measure of the absorbed dose.

${ }^{26}$ Data are taken from the official report "20 Years After Chernobyl Catastrophe. Future Outlook: National Report of Ukraine,” Tables 3.3.7 and 3.3.9 (Baloga, Kholosha, and Evdin 2006, pages 45, 47, 48).
} 
As an alternative measure, we collapse the five-point life satisfaction variable into a binary dependent variable (unhappy), identifying all individuals who answered being fully dissatisfied with their life ( $21 \%$ of the sample). In addition, we use two further dependent variables. The first is a binary variable indicating whether the respondent has been diagnosed for six months or longer with depression or chronic anxiety (UHBS data). The second dependent variable is subjective survival probability which is based on a question covered in the ULMS wave 2007. Individuals aged 46 and above were asked to rate the probability that they would survive until a certain target age in the future. ${ }^{27}$ This target age is 65 for all respondents aged 46 to 55, 70 for those aged 56 to 60,75 for those aged 61 to 65 , and 80 for those above 66. If Chernobyl increased individual worries about future adverse health outcomes and lowered mental well-being, we expect more affected persons to report lower subjective survival probabilities.

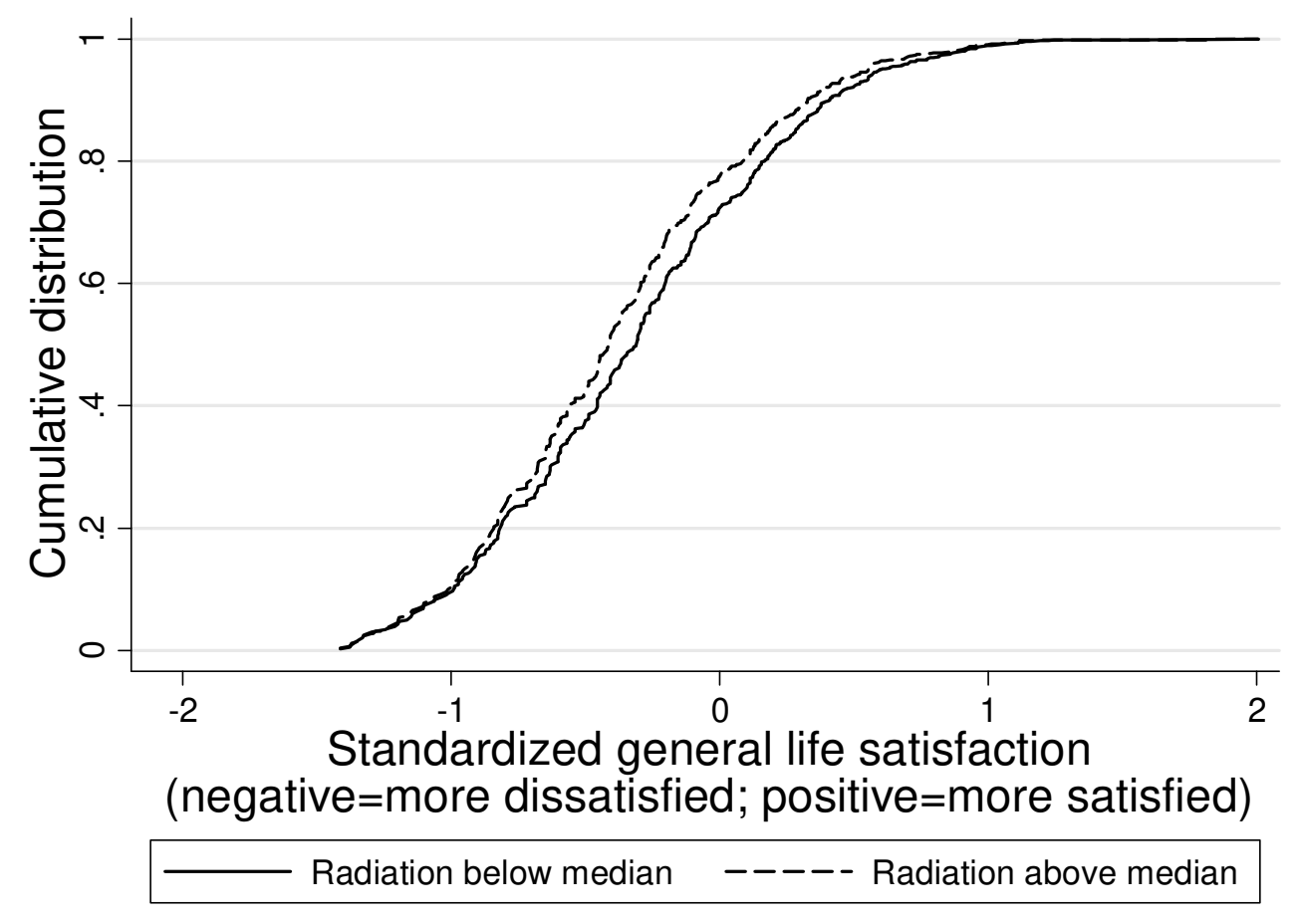

Fig. 1: Cumulative distribution of life satisfaction

Source: Conditional distribution, controlling for age and time fixed effect, ULMS 2003-2007, number of observations: 11,922; own calculations.

\footnotetext{
${ }^{27}$ There are 1,958 observations in the estimation sample for which this variable is non-missing. The mean of this variable is $53.9 \%$ (standard deviation of 27.0 ).
} 


\subsection{Estimation strategy}

We estimate the long-term effects of the Chernobyl catastrophe on standardized mental well-being and other outcomes $y$ based on the following model:

$$
y_{i k t}=\beta_{0}+\beta_{1} \text { Radiation }_{k 86}+X^{\prime} \gamma+\tau_{k}+\sigma_{t}+\varepsilon_{i k t} .
$$

Radiation is the objectively measured exposure dose that individual $i$ received according to her place of residence $k_{86}$ in 1986 (standard errors are clustered at the $k_{86}$ level). For ease of interpretation we express the radiation measure in terms of units of natural background radiation. The coefficient of interest is $\beta_{1}$, which measures the impact of one unit of natural background radiation on our outcome measures $y$ at time $t$. Long-term negative psychological effects of the Chernobyl catastrophe would yield a negative $\hat{\beta}_{1}$. Without adding further controls for potential channels to the regressions, $\hat{\beta}_{1}$ should capture the net reduced form long-term effect of the nuclear accident on today's mental well-being. However, to account for possible channels through which Chernobyl might have affected long-term wellbeing, different sets of control variables are included in $X$ one after the other. Initially, predetermined personal characteristics (gender and age ${ }^{28}$ ) are added to the regressions. This is followed by education and marital status, as well as proxies for the physical health status of individuals. ${ }^{29}$ We also add a set of dummy variables for current labour force participation status, household size, log of per-capita household income, living space per capita as a proxy for permanent income or wealth and type of settlement (village, town, or city). If these sets of variables reflected different transmission channels, their inclusion should gradually reduce the overall size of the $\hat{\beta}_{1}$ coefficient. Furthermore, after controlling for these various channels, the $\hat{\beta}_{1}$ coefficient represents the long-run effect of the catastrophe conditional on individual coping and adaptive behaviour (which could either mitigate or exacerbate the Chernobyl effect). All regressions control for administrative region $k$ (26 oblasts), year $t$, and month of

\footnotetext{
${ }^{28}$ While the literature has often assumed a u-shaped pattern between age and subjective well-being, we allow for greater flexibility by using age fixed effects. However, our results remain virtually unchanged if we, like other researchers, apply linear, quadratic, or cubic age specifications (Blanchflower and Oswald 2008). Our results are also robust to controlling for the natural logarithm of age in order to account for the subjective feeling that time passes more quickly as individuals age (van Praag and Baarsma 2005) (see Appendix, Table A-5).

${ }^{29}$ The health measures are (1) a dummy variable for all individuals having at least one of seven different chronic physical diseases (chronic: heart disease, illness of the lungs, liver disease, kidney disease, gastrointestinal disease, spinal problems, or other chronic illnesses) and (2) the individual's height (height). We also add measures of risky behaviour (smoking and drinking).
} 
interview $m$ fixed effects. $\varepsilon_{i k t}$ is an iid error term. Variable definitions and descriptive statistics of all variables are provided in Tables A-3 and A-4.

We estimate Equation (1) with OLS. While OLS estimates are intuitive to interpret and are consistent under classical assumptions, they do not account for the categorical character of the dependent variable (and are therefore less efficient). To test the sensitivity of the results we re-estimate our main models with ordered Probit, interval regression, random effects GLS, Probit and linear probability methods.

\section{Results: Long-Term Effects of the Chernobyl Disaster on Mental Well-Being}

Greater disaster impact reduces contemporary well-being even 20 years after Chernobyl: The effect associated with an increase of one unit of natural background radiation reduces life satisfaction by $18 \%$ of a standard deviation (Table 1). Adding predetermined demographic characteristics (age and gender) reduces the size of the estimated effect only marginally (Column 2). In general, men seem to be significantly more satisfied with their lives than women (however, the gender coefficient becomes smaller and insignificant once further controls are included in the estimation). Column 3 includes all other individual and household level controls. Being married, more years of schooling, as well as higher household income are associated with higher levels of life satisfaction-in line with the large literature on subjective well-being. For instance, our income coefficient compares well to the estimate in Frijters, Haisken-DeNew and Shields (2004) using German data. ${ }^{30}$ Equally unsurprising, persons suffering from chronic illnesses have a lower life satisfaction than healthy persons. The coefficient of being unemployed is sizeable and more than twice as large as the coefficient on bad health-similar to the previous literature (Winkelmann and Winkelmann 1998). However, despite controlling for these potential channels, the coefficient of the radiation variable remains remarkably stable across all specifications indicating a significant and long-term negative effect of the Chernobyl catastrophe on subjective well-being. This effect holds equally for different subgroups (men and women, young and old). ${ }^{31}$ Our findings remain qualitatively identical when we use information on absorbed doses of iodine-131 by children aged zero to 18 at the time of the catastrophe as alternative measure for radiation exposure (Column 4 of Table 1).

\footnotetext{
${ }^{30}$ Since their estimate refers to an 11-point-scale life satisfaction variable, we rescale our estimates.

${ }^{31}$ See Tables A-6 in the Appendix.
} 
Table 1: The long-run effect of Chernobyl on life satisfaction

Dependent variable

(2)

(3)

(4)

(1)

Life satisfaction

Radiation

$-0.183 * * *$

$-0.159 * * *$

$-0.196 * * *$

$(0.061)$

(0.054)

(0.052)

Radiation iodine-131

Male

$0.075 * * *$

(0.016)

0.028

$(0.027)$

$-0.012 * * *$

(0.002)

Married

$0.229 * * *$

0.029

$(0.058)$

Widowed

(0.047)

$0.311 * * *$

$0.107 * *$

(0.047)

(0.050)

0.221

0.030

(0.256)

Separated

(0.049)

$0.098 * *$

Years of schooling

$0.038 * * *$

$(0.045)$

(0.005)

$0.049 * * *$

Chronic

$-0.217 * * *$

(0.010)

(0.016)

$-0.187 * * *$

0.009

(0.030)

Drinker

(0.069)

$-0.234 * * *$

Smoker

$-0.084 * * *$

$(0.081)$

(0.021)

$-0.055$

$0.003 *$

$(0.038)$

Height

(0.001)

0.004

$-0.491 * * *$

(0.002)

Unemployed

(0.028)

$-0.559 * * *$

$-0.183 * * *$

(0.051)

Pensioner

(0.042)

Inactive

$-0.155^{* * *}$

$-0.072$

(0.034)

$(0.057)$

$-0.014$

$-0.014$

(0.011)

$(0.015)$

Log income

$0.152 * * *$

$0.124 * * *$

(0.016)

(0.021)

$0.037 * * *$

0.025

Space pc

(0.010)

Region FE

Year FE

Month FE

Place FE

Age FE

Observations
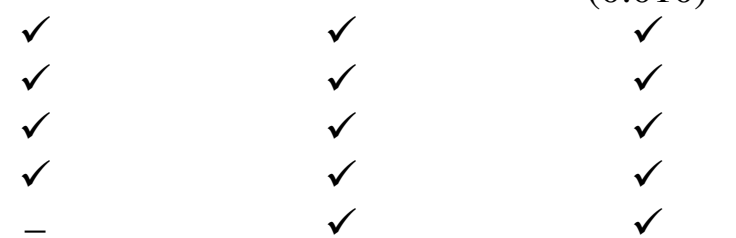

$(0.021)$

R-squared

11,922

11,922

11,922

0.121

0.200

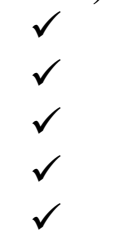

0.081

Notes: Dependent variable is standardized with mean of zero and std. of one. Iodine-131 is measured in logs. Robust standard errors clustered by region of radiation in parentheses. $* * * \mathrm{p}<0.01, * * \mathrm{p}<0.05, * \mathrm{p}<0.1$. Source: ULMS 2003-2007; own calculations. The regression in column 4 is based on the subsample of persons aged 0 to 18 in 1986. 
Furthermore, the results are robust to alternative estimation methods and to estimating separate regressions for each survey wave. ${ }^{32}$ The latter finding shows the persistence of the Chernobyl effect across years and hence counters one often articulated critique that subjective well-being measures may exclusively capture emotional affect at the survey date. To test whether our results are driven by one single (most affected) region, we repeat the analysis excluding each of the seven most affected regions one at a time (Table A-9 in the Appendix). Again, the results remain very similar. We also demonstrate that our results are not confounded by respondents who either lived in 1986 or live today close to an active nuclear power plant by adding a dummy variable indicating the presence of a nuclear power plant in the region of residence and its interaction with radiation (Table A-10 in the Appendix).

Finding significant results after 20 years indicates that life satisfaction has not returned to its baseline, suggesting no full adaptation to the catastrophe. This is in line with recent economic studies on idiosyncratic strokes of fate (e.g., Oswald and Powdthavee 2008; Powdthavee and Stutzer 2014). Yet, the Chernobyl disaster differs from such shock, since it has not significantly deteriorated the physical health of the general population (Lehmann and Wadsworth 2011). Instead it raised the potential risk of and worries about adverse future health conditions.

\subsection{Further evidence on objective mental well-being}

Do the results on lower life satisfaction reflect a deterioration of the mental health of the general Ukrainian population? We complement our analysis of subjective well-being by estimating the effect of Chernobyl on objective mental health outcomes using diagnosed depression and anxiety in the nationally representative UHBS survey. The overall depression incidence rate in Ukraine is high in international comparison (9\%; WHO World Mental Health Survey Consortium 2004). Yet, only $3 \%$ of the population are actually diagnosed by a physician with a depression (Wang et al. 2007), a number that matches the incidence rate in our data set (3\% in UHBS). The vast majority of mental disorders remains undetected in developing and emerging countries, as service coverage remains poor (Bromet, Havenaar and Guey 2011; Wang et al. 2007; WHO World Mental Health Survey Consortium 2004).

\footnotetext{
${ }^{32}$ See Tables A-7 and A-8 in the Appendix. The marginal effects for the five different satisfaction outcomes in the ordered Probit model show that higher radiation significantly increases the probability of reporting lower levels of life satisfaction and decreases the probability of reporting higher levels of life satisfaction. The marginal effects from the Probit regressions (dependent variable unhappy) imply that one unit of background radiation increases the likelihood that individuals are unhappy with their life by about 10 percentage points.
} 
Table 2: The Chernobyl effect on diagnosed mental disorders

(1)

Dependent variable

Radiation

Subjective affectedness

Full set of controls

Local doctor contact rates

Observations

R-squared

0.011 et of cos is a dummy variable for individuals repoting that their health has been affected by Chernobyl. Full set controls as in Table 1, column 3, and the interregional migration matrix 1986-2003. Standard errors clustered at oblast level in parentheses. ${ }^{* * *} \mathrm{p}<0.01, * * \mathrm{p}<0.05, * \mathrm{p}<0.1$. Source: UHBS 2004-2006; sample restricted to match the ULMS sample definitions.

In Table 2 we present regression results where the dependent variable is a binary indicator for having been diagnosed with depression or chronic anxiety. ${ }^{33}$ To identify individuals who have been affected by the Chernobyl catastrophe, we use objective radiation doses reweighted by the inter-regional migration matrix between 1986 and $2003 .{ }^{34}$ Alternatively, and as a robustness check, we use a binary indicator for Chernobyl exposure based on a subjective assessment of whether a respondent's health was affected by the nuclear disaster. ${ }^{35}$ The regression results reveal that higher exposure doses significantly increase the likelihood of suffering from depression or chronic anxiety 20 years after the disaster (column 1). A one unit increase in natural background radiation raises the incidence of diagnosed mental disorders by about 1.7 percentage points in the general population. The subjective affectedness measure yields similar results (column 2). Although it is re-assuring to find similar effects using two different measures of affectedness, the results using the second measure should be interpreted cautiously due to the potential endogeneity of the subjective affectedness measure.

Areas with more radiation were subject to more extensive medical screenings (WHO 2006). To rule out potential supply side effects of medical check-ups, we conduct a robustness check by controlling for average local doctor contact rates (computed at the sub-regional level in the UHBS data). The qualitative results remain unchanged (columns 3 and 4).

\footnotetext{
${ }^{33}$ Given that the diagnoses are self-reported, this variable might suffer from measurement error (e.g., through under-reporting due to stigma).

${ }^{34}$ We also control for the inter-regional migration matrix between 1986 and 2003.

${ }^{35}$ The question in the UHBS questionnaire reads: "Has your health been affected by the Chernobyl catastrophe?"
} 


\subsection{Possible interpretation: Reduced subjective life expectancy}

Can these significant long-run Chernobyl effects on subjective and objective mental health by explained by greater anxiety and uncertainty about future health status described in Section 1.2? While a direct measure on this channel does not exist, the ULMS survey provides information on subjective life expectancy in the form of subjective survival probabilities. If the disaster increased respondents' worries about their future health outcomes, we expect affected persons to report lower subjective survival probabilities. And indeed, the results in Table 3 reveal that Chernobyl has significantly reduced subjective life expectancies. In the full specification (column 3), one additional unit of natural background radiation reduces the expected survival probability by 7.5 percentage points, which is equivalent to a reduction by $28 \%$ of a standard deviation. Previous research on subjective survival probabilities in industrialized countries suggests that subjective measures of life expectancy are internally consistent with actual objective health risks (Brouwer and van Exel 2005; Hamermesh 1985; Hurd and McGarry 2002). This would imply for our results that affected individual have a shorter life span on average, but that the loss in actual life time might be larger or smaller than suggested by the estimates.

Table 3: Impact of affectedness on subjective survival probability

\begin{tabular}{lccc}
\hline Dependent variable & $(1)$ & $(2)$ & $(3)$ \\
\hline & Subjective probability of survival to target age (0\% to 100\%) \\
\hline Radiation & $-10.391 * * *$ & $-7.417 * * *$ & $-7.500 * *$ \\
& $(3.381)$ & $(2.526)$ & $(2.739)$ \\
Year FE & $\checkmark$ & $\checkmark$ & $\checkmark$ \\
Month FE & $\checkmark$ & $\checkmark$ & $\checkmark$ \\
Region FE & $\checkmark$ & $\checkmark$ & $\checkmark$ \\
Place FE & $\checkmark$ & $\checkmark$ & $\checkmark$ \\
Age and Gender & - & $\checkmark$ & $\checkmark$ \\
Remaining controls & - & - & 1,958 \\
Observations & 1,958 & 1,958 & 0.246 \\
R-squared & 0.138 & 0.203 & $\checkmark$ \\
\hline
\end{tabular}

Notes: The target age is 65 for those aged 46 to 55,70 for those aged 56 to 60,75 for those aged 61 to 65 , and 80 for those aged 66 to 75. The included control variables are as in Table 1. The questions on the survival probabilities were asked only to individuals aged 46 and above and only in the ULMS 2007. Standard errors clustered by radiation region as of 1986 in parentheses. $* * * \mathrm{p}<0.01, * * \mathrm{p}<0.05, * \mathrm{p}<0.1$ Source: ULMS 2007. 


\subsection{Discussion and further implications}

Our evidence unambiguously points to a large negative long-run effect of the Chernobyl disaster on subjective well-being and objective mental health. The persistence of the effect seems to stem from the uncertainty regarding individual health consequences as suggested by significantly reduced subjective survival probabilities. Importantly, the negative Chernobyl effect is already net of physical health conditions, i.e. conditioning on the most highly discussed transmission channel. This is in line with previous evidence which finds no adverse physical health effects for the adult population (Lehmann and Wadsworth 2011). Hence, we provide the first representative and long-term evidence that the most relevant public health consequences for the general population relate to mental health.

Psychologists postulate that affected individuals who suffer from psychological illnesses, depression or anxiety exhibit higher levels of lethargy and listlessness (Osiatynski 2004; Udovyk 2007). We hypothesize that such feeling of powerlessness and the perception of not being able to help oneself might cause a greater dependency on social benefits. So far, no quantitative assessment of this potential behavioural long-term implication of Chernobyl exists. This behavioural effect is estimated based on differences in social benefit dependency between more and less affected individuals. For the dependent variable we calculate the share of social transfers in total household income as reported by household heads in the ULMS (excluding any Chernobyl assistance payments). ${ }^{36}$ This exercise focuses on working-age adults to account for the fact that most pension-aged individuals in Ukraine rely exclusively on state benefits and that pension benefits are de-facto almost uniform and paid out to all elderly (Danzer 2013). ${ }^{37}$

In line with our conjecture, we find a significant positive effect of Chernobyl on transfer dependency: affected working-aged persons have a 3.5-4.4 percentage point higher transfer share in total income (Table 4). Using these estimates we calculate the fiscal equivalents of these additional social transfers accruing to the state at $0.5-0.6 \%$ of GDP. Higher benefit receipt in the working age population might not in itself be considered a direct economic loss as benefits are merely redistributed across population subgroups. There is, however, a deadweight loss of taxation (Gruber 2010). Assuming a deadweight loss of 0.4 per

\footnotetext{
${ }^{36}$ Household income includes all types of payments (including payments in the form of goods and services) and transfers that the household received in the last month (after tax).

${ }^{37}$ Due to the Soviet full employment policy, all elderly are eligible for a full old-age pension.
} 
US dollar yields an aggregate welfare loss over a 20 year period of $20 \times 0.5 \times 0.4=4 \%$ of Ukraine's GDP in 2004.

Table 4: Transfer dependency in working-age adults

\begin{tabular}{lccc}
\hline Dependent variable & $(1)$ & $(2)$ & $(3)$ \\
\hline & & Transfer share in income (\%) & \\
Radiation dose & $0.044^{* * *}$ & $0.036^{* *}$ & $0.035^{* *}$ \\
& $(0.014)$ & $(0.016)$ & $(0.014)$ \\
Implied aggregate cost in \% of & & & \\
annual GDP & $0.60 \%$ & $0.50 \%$ & $0.49 \%$ \\
Year FE & $\checkmark$ & $\checkmark$ & $\checkmark$ \\
Month FE & $\checkmark$ & $\checkmark$ & $\checkmark$ \\
Region FE & $\checkmark$ & $\checkmark$ & $\checkmark$ \\
Place FE & $\checkmark$ & $\checkmark$ & $\checkmark$ \\
Age and Gender & - & $\checkmark$ & $\checkmark$ \\
Remaining controls & - & - & 7,985 \\
Observations & 7,985 & 7,985 & 0.226 \\
R-squared & 0.095 & 0.140 & \\
\hline
\end{tabular}

Notes. OLS models. The included control variables are as in Table 1 plus dummies for the number of working and the number of pension-recipient household members. Working age is up to age 55 (60) for women (men). Robust standard errors clustered by radiation region in parentheses. The formula for the implied aggregate cost in \% of annual GDP is $\left(\sum_{i=1}^{I} Y_{i} \times N_{W A} / N_{A} \times \beta_{1}\right) / G D P$, with $Y_{i}$ denoting annual income of household $i$ and $N$ denoting number of household members who are adults $(A)$ or of working age $(W A)$.*** p<0.01, ** p $<0.05$, * $\mathrm{p}<0.1$. Source: ULMS 2003-2007; own calculations.

\section{The monetary evaluation of the aggregate welfare loss}

The identified mental and well-being effects at the individual level point to a significant aggregate welfare loss in the general (low-dose) population. This aspect of the catastrophe has received very little attention in the political and academic debate and has not been included in any cost assessment of the Chernobyl disaster to date. We fill this gap by computing the monetary value of the welfare loss.

Since catastrophes can only be evaluated ex-post, hedonic ex-ante approaches are not applicable. The most suitable methods for computing the monetary welfare loss seem to be either stated preference (explicit willingness to pay) or subjective well-being approaches (which allow calculating an implicit willingness to pay; see Levinson 2012). In the context of nuclear power, the former method has been applied for the ex-ante willingness to accept 
compensation in exchange for the location of a nearby underground nuclear waste repository in Nevada, USA. Kunreuther and Easterling (1990) conducted a telephone survey offering randomized compensation packages to local residents but found that the compensation was most often deemed inappropriate because of security worries. Taking into account additional concerns about strategic responses and framing effects inherent to this method (Levinson 2012) we follow the subjective well-being approach. The goal of this approach is to ex-post estimate the amount of monetary compensation required to close the relative mental wellbeing gap of the affected (Clark and Oswald 2002; Levinson 2012). In this framework Equation (1) represents a utility or utilitaristic welfare function in which life satisfaction is assumed to proxy for directly experienced utility. Thus, the coefficient of radiation expresses the marginal disutility from the disaster. Using the marginal rate of substitution between radiation and income (the relative size of the affectedness to the income coefficient), we compute the monetary compensating differential required to make affected and unaffected individuals equally well-off. ${ }^{38}$

We perform the analysis for three scenarios: In the first one, every Ukrainian citizen is compensated according to her "assigned" radiation dose from 1986. The second and third scenarios use specific radiation thresholds $z\left(z_{1}=0.6 \mathrm{mSv}\right.$ and $\left.z_{2}=0.8 \mathrm{mSv}\right)$ above which citizens are compensated with a unitary benefit while persons below the threshold remain uncompensated. To attain the relevant coefficients for the threshold models we estimate semi$\log$ Equation (2) in which $\hat{\beta}_{\text {inc }}$ gives the change in the dependent variable $y$ (utility) due to a one log point change in uncompensated total monthly household income ${ }^{39}$ (expressed in June 2004 values), while the utility loss due to radiation above threshold $z$ (indicated by a dummy variable) is given by $\hat{\beta}_{\text {rad }, z}::^{40}$

$$
\begin{gathered}
y_{i k t}=\beta_{0}+\beta_{\text {rad }, \mathrm{Z}} \text { RadiationDummy } \text { R }_{k 6, z}+\beta_{\text {inc }} \log \left(\text { income }_{i t}\right)+ \\
X^{\prime} \gamma+\tau_{k}+\sigma_{t}+\varepsilon_{i k t} .
\end{gathered}
$$

We then aggregate and express the relative income change required for neutralizing the negative disaster effect as a fraction of annual GDP:

\footnotetext{
${ }^{38}$ This approach does not come without strong assumptions. However, as discussed and highlighted by Levinson (2012), these are no stronger than the assumptions underlying alternative methods.

39 There are several advantages to using household instead of individual income: households tend to pool resources and also have joint expenditures and the measure of household income provides a more complete assessment of non-wage income sources.

${ }^{40}$ The base category comprises individuals with additional radiation below $0.2 \mathrm{mSv}$.
} 


$$
\left[\left(\exp \left(\frac{-\widehat{\beta}_{\text {rad }}}{\widehat{\beta}_{\text {inc }}}\right)-1\right) \times \bar{Y}_{\text {household }}^{\text {uncomp }} \times 12 \times \frac{N}{\text { household size }}\right] / G D P
$$

with $\bar{Y}_{\text {household }}^{\text {uncomp }}$ being the average uncompensated monthly household income and $N$ being the size of the compensated population.

The results of these calculations are presented in Table 5: Compensation equals 76$110 \%$ of average monthly household income, or 69-100 USD per household and month. ${ }^{41}$ Clearly, compensating only the more affected individuals raises the monthly amount per household but reduces the population base receiving benefits. The aggregate welfare loss adds up to additional $6.3-8.4 \%$ of Ukrainian GDP per year. This implies that the uncompensated costs even slightly exceed the explicit current disaster relief and liquidation spending (5-7\% of GDP; Oughton, Bay-Larsen and Voigt 2009).

Table 5: Compensating differentials and share of total compensation in GDP

\begin{tabular}{llcccc}
\hline & \multicolumn{1}{c}{$\begin{array}{c}\widehat{\boldsymbol{\beta}}_{\text {rad }} \\
\text { (in units of } \\
\text { background } \\
\text { radiation) }\end{array}$} & $\boldsymbol{e x p}\left(\frac{-\widehat{\boldsymbol{\beta}}_{\text {rad }}}{\widehat{\boldsymbol{\beta}}_{\text {inc }}}\right)$ & $\begin{array}{c}\text { Compen- } \\
\text { sated } \\
\text { population } \\
\text { (mio.) }\end{array}$ & $\begin{array}{c}\text { Monthly } \\
\text { household } \\
\text { compensating } \\
\text { differential } \\
\text { (in USD) }\end{array}$ & $\begin{array}{c}\text { Share } \\
\text { of } \\
\text { annual } \\
\text { GDP }\end{array}$ \\
\hline I. $\quad \begin{array}{l}\text { Compensation w/o } \\
\text { threshold }\end{array}$ & -0.196 & 1.76 & 38.1 & 68.7 & $8.4 \%$ \\
II. $\quad \begin{array}{l}\text { Medium radiation } \\
\text { threshold }\end{array}$ & -0.226 & 1.92 & 31.6 & 83.1 & $8.0 \%$ \\
III. $\quad \begin{array}{l}\text { High radiation } \\
\text { threshold }\end{array}$ & -0.258 & 2.10 & 20.8 & 99.9 & $6.3 \%$ \\
\hline
\end{tabular}

Notes: The coefficients for computing (3) are measured in $\mathrm{mSv}\left[\hat{\beta}_{\text {rad }} / 2\right]$. The estimates stem from regressions including the full set of controls as in Table 1, column (3). The radiation thresholds are: medium- $-0.6 \mathrm{mSv}$; high $-0.8 \mathrm{mSv}$. All reported coefficients are significantly different from zero. Income is measured in log.

\section{Conclusions}

This paper sheds slight on the hidden and previously unquantified welfare loss from the largest nuclear accident on record. We analyse the effects of the Chernobyl disaster on mental well-being of the general population in Ukraine 20 years after the accident. To identify the causal effect of Chernobyl we assign regional radiation doses to individuals according to their place of residence at the time of the catastrophe. The results suggest that affected

\footnotetext{
${ }^{41}$ In comparison, the compensating differential for suffering from a chronic physical disease is 226 USD.
} 
individuals exhibit significantly lower levels of mental well-being as demonstrated by reduced life satisfaction and increased incidence rates of depression and chronic anxiety. We provide suggestive evidence that worries about future health outcomes are one significant transmission channel through which the catastrophe impacted mental well-being: Affected individuals report significantly lower subjective survival probabilities which points to a reduced perceived life expectancy. As a behavioural consequence, we find that more affected individuals rely to a greater extent on governmental social benefits as a source of livelihood, accruing to $0.5 \%$ of GDP per year. Taking our results one step further, we estimate the aggregate annual compensating differential needed to offset the long-run welfare loss of the general population at $6.3-8.4 \%$ of Ukraine's GDP. This suggests that the overall costs to society caused by the Chernobyl catastrophe significantly exceed the actual liquidation and recovery costs of around 5-7\% of GDP per year.

This paper has exploited governmental countermeasures against the disaster as signals for affectedness. Yet, we caution the reader not to conclude that these countermeasures were irresponsible. Not only is the counterfactual without any countermeasures unknown; in fact, politicians had to respond very quickly in 1986 without today's available knowledge about realized consequences. However, the information policy of governments in the aftermath of such accidents is an extremely difficult challenge and responsible actors have tended to downplay the true risks - thus endangering a loss in credibility; this also holds for advanced democracies. The literature on risk communication suggests that more credible information about the potential impact of the disaster might have reduced the negative mental toll taken by the catastrophe (Rubin et al. 2012). In general, post-disaster psychological morbidity can be further reduced by adequate mental health interventions and sufficient provision of mental health care services (Bromet, Havenaar and Guey 2011).

The world has seen 25 nuclear accidents in the past 60 years and many more technical disasters (Sovacool 2008) suggesting that the largest nuclear catastrophe provides lessons beyond Ukraine. As the catastrophes in the Fukushima Daiichi (Japan, 2011) and Three Mile Island (USA, 1979) nuclear power plants have clearly shown, such accidents can happen everywhere, even in the richest countries with the highest safety and security standards. Our study provides unique policy relevant evidence about a previously neglected welfare consequence of nuclear accidents-an important aspect which probably applies to technological disasters in general. This can inform governments which ultimately have to bear 
the costs of nuclear and other large-scale accidents due to the lack or limitation of private insurance (Faure and Skogh 1992; Laes, Meskens and van der Sluijs 2011). History has shown that the costs caused by nuclear accidents have to be borne by the taxpayer no matter whether nuclear power is produced by private or state owned companies. Cost-benefit analyses of energy technologies should recognize these individual and aggregate well-being and welfare consequences of high-cost, low-frequency disasters.

\section{References}

Abbott, Pamela, Claire Wallace and Matthias Beck. 2006. "Chernobyl: Living with risk and uncertainty." Health Risk \& Society, 8 (2): 105-121.

Almond Douglas, Lena Edlund and Mårten Palme. 2009. “Chernobyl’s subclinical legacy: Prenatal exposure to radioactive fallout and school outcomes in Sweden." Quarterly Journal of Economics, 124 (4): 1729-1772.

Baloga, V. I, V. I. Kholosha and O. M. Evdin (eds.). 2006. 20 years after Chernobyl catastrophe. Future outlook: National report of Ukraine. Kiev: Atika.

Berger, Eva M. 2010. “The Chernobyl disaster, concern about the Environment, and life satisfaction." Kyklos, 63 (1): 1-8.

Black, Sandra E., Aline Bütikofer, Paul J. Devereux and Kjell G. Salvanes. 2013. This Is Only a Test? Long-Run Impacts of Prenatal Exposure to Radioactive Fallout. NBER Working Paper No. 18987.

Blanchflower, David G. and Andrew J. Oswald. 2008. "Is well-being U-shaped over the life cycle?" Social Science \& Medicine, 66 (8): 1733-1749.

Bromet, Evelyn J. and Johan M. Havenaar. 2007. "Psychological and perceived health effects of the Chernobyl disaster: A 20-year review." Health Physics, 93 (5): 516-521.

Bromet, Evelyn J., Johan M. Havenaar and L.T. Guey. 2011. “A 25 Year Retrospective Review of the Psychological Consequences of the Chernobyl Accident." Clinical Oncology, 23 (4): 297-305.

Brouwer, Werner B.F. and N.J.A. van Exel. 2005. "Expectations regarding length and health related quality of life: Some empirical findings." Social Science \& Medicine, 61 (5): 1083-1094.

IAEA. 2005. Chernobyl's Legacy: Health, Environmental and Socio-Economic Impacts. Chernobyl Forum. Retrieved 03 May 2014. URL: http://www.iaea.org/Publications/ Booklets/ Chernobyl/chernobyl.pdf.

Clark, Andrew E., Paul Frijters and Michael A. Shields. 2008. "Relative income, happiness, and utility: An explanation for the Easterlin paradox and other puzzles." Journal of Economic Literature, 46 (1): 95-144. 
Clark, Andrew E. and Andrew J. Oswald. 2002. "A simple statistical method for measuring how life events affect happiness." International Journal of Epidemiology, 31 (6): 1139-1144.

Danzer, Alexander M. 2013. "Benefit Generosity and the Income Effect on Labour Supply: Quasi-Experimental Evidence.” Economic Journal, 123 (571): 1059-1084.

Demidchik, Evgeny P., Anton Mrochek, Yuri Demidchik, Tatiana Vorontsova, Eugeny Cherstvoy, Jacov Kenigsberg, V. Yuri Rebeko and Akira Sugenoya. 1999.

"Thyroid cancer promoted by radiation in young people of Belarus (clinical and epidemiological features)." In Thomas, G., A. Karaoglou and E.D. Williams (eds.), Radiation and Thyroid Cancer. Proceedings of the International Seminar on Radiation and Thyroid Cancer. Brussels, Luxembourg: World Scientific.

European Commission. 1998. Atlas of Caesium Deposition on Europe After the Chernobyl Accident. Edinburgh: Edinburgh Press.

European Commission. 2004. Actions against depression. Improving mental and well-being by combating the adverse health, social and economic consequences of depression. Retrieved 04 June 2014. URL: http://ec.europa.eu/health/archive/ph_determinants/ life_style/mental/docs/depression_en.pdf.

Faure, Michael G. and Göran Skogh. 1992. "Compensation for Damages Caused by Nuclear Accidents: A Convention as Insurance." The Geneva Papers on Risk and Insurance, 17: 499-513.

Firsakova, S.K. 1993. "Effectiveness of countermeasures applied in Belarus to produce milk and meat with acceptable levels of radiocaesium after the Chernobyl accident." The Science of the Total Environment, 137: 199-203.

Frey, Bruno S., Simon Lüchinger and Alois Stutzer. 2010. "The Life Satisfaction Approach to Environmental Valuation.” Annual Review of Resource Economics, 2:139-60.

Frijters, Paul, John P. Haisken-DeNew and Michael A. Shields. 2004. "Money Does Matter! Evidence from Increasing Real Income and Life Satisfaction in East Germany Following Reunification” American Economic Review, 94 (3): 730-740.

Gargiulo, R. Adriana and Mark A. Stokes. 2009. "Subjective well-being as an indicator for clinical depression." Social Indicators Research, 92(3): 517-527.

Gould, Peter. 1990. Fire in the Rain: The Democratic Consequences of Chernobyl. Baltimore, MD: Johns Hopkins University Press.

Gregory, Paul R. and Janet E. Kohlhase. 1988. "The earnings of Soviet workers: Evidence from the Soviet Interview Project." Review of Economics and Statistics, 70 (1): 23-35.

Greenpeace. 2006. The Chernobyl Catastrophe: Consequences for Human Health. Greenpeace: Amsterdam.

Gruber, Jonathan. 2010. Public Finance and Public Policy. 3rd ed. New York: Worth Publishers.

Halla, Martin and Martina Zweimüller. 2014. Parental Response to Early Human Capital Shocks: Evidence from the Chernobyl Accident. IZA Discussion paper No. 7968. 
Hamermesh, Daniel S. 1985. "Expectations, Life Expectancy, and Economic Behavior." Quarterly Journal of Economics, 100 (2): 389-408.

Havenaar, Johan M., Galina M. Rumyantzeva, Wim van den Brink, Nico W. Poelijoe, Jan van den Bout, Herman van Engeland and Maarten W. J. Koeter. 1997. "Long-term mental health effects of the Chernobyl disaster: An epidemiologic survey in two former Soviet regions." American Journal of Psychiatry, 154 (11): 1605-1607.

Headey, B.W., J. Kelley and A.J. Wearing. 1993. "Dimensions of mental health: Life satisfaction, positive affect, anxiety, and depression.” Social Indicators Research, 29: 63-82.

Hurd, M. D. and K. McGarry. 2002. "The Predictive Validity of Subjective Probabilities of Survival." Economic Journal, 112: 966-985

Ivanov, Victor K., Anton I. Gorski, Marat A. Maksioutov, Anatoly F. Tsyb and Anton G. Souchkevitch. 2001. "Mortality among the Chernobyl emergency workers: Estimation of radiation risks." Health Physics, 81 (5): 514-521.

Kimball, Miles, Helen Levy, Fumio Ohtake and Yoshiro Tsutsui. 2006. "Unhappiness after Hurricane Katrina.” NBER Working Paper No. 12062.

Kunreuther, Howard and Douglas Easterling. 1990. "Are Risk-Benefit Tradeoffs Possible in Siting Hazardous Facilities?" American Economic Review, 80 (2): 252-256.

Laes, Erik, Gaston Meskens and Jeroen P. van der Sluijs. 2011. "On the contribution of external cost calculations to energy system governance: The case of a potential largescale nuclear accident." Energy Policy, 39: 5664-5673.

Lee, T.R. 1996. Environmental stress reactions following the Chernobyl accident. in: One Decade After Chernobyl. Summing up the Consequences of the Accident. Proceedings of an International Conference, Vienna. STI/PUB/1001. IAEA: Vienna: 283-310.

Lehmann, Hartmut and Jonathan Wadsworth. 2011. "The impact of Chernobyl on health and labour market performance." Journal of Health Economics, 30 (5): 843-857.

Lehmann, Hartmut, Alexander Muravyev and Klaus F. Zimmermann. 2012. "The Ukrainian longitudinal monitoring survey: towards a better understanding of labor markets in transition." IZA Journal of Labor \& Development, 1: 9.

Levinson, Arik. 2012. "Valuing public goods using happiness data: The case of air quality." Journal of Public Economics, 96: 869-880.

Likhtarev I.A., G.M. Guiko, B.G. Sobolev, I.A. Kairo, N.I. Chepurnoy, G. Pröhl and K. Henrichs. 1994 "Thyroid dose assessment for the Chernigov region (Ukraine): Estimation based on 131I thyroid measurements and extrapolation of the results to districts without monitoring." Radiation and Environmental Biophysics, 33:149-166.

Loganovsky, Konstantin, Johan M. Havenaar, Nathan L. Tintle, Lin T. Guey, Roman Kotov and Evelyn J. Bromet. 2008. "The mental health of clean-up workers 18 years after the Chernobyl accident." Psychological Medicine, 38 (4): 481-488.

Lüchinger, Simon. 2009. "Valuing Air Quality Using the Life Satisfaction Approach." Economic Journal 119(536): 482-515. 
Lüchinger, Simon and Paul A. Raschky. 2009. "Valuing flood disasters using the life satisfaction approach.” Journal of Public Economics, 93 (3-4): 620-633.

Metcalfe, Robert, Nattavudh Powdthavee and Paul Dolan. 2011. "Destruction and distress: Using a quasi-experiment to show the effects of the September 11 attacks on mental well-being in the United Kingdom.” Economic Journal, 121 (550): F81-F103.

Mettler, F.A. Jr., H.D. Royal, J.R. Hurley et al. 1992. "Administration of stable iodine to the population around the Chernobyl nuclear power plant." Journal of Radiological Protection, 12(3): 159-165.

Mitsikostas, Dimos D., Leonidas Mantonakis and Nikolaos Chalarakis. 2014. "Nocebo in clinical trials for depression: A meta-analysis.” Psychiatry Research, 215(1): 82-86.

Osiatynski, Jerzy. 2004. Ukrainian Chernobyl national programs enhancement. Analytical study for UNDP. Mimeo.

Oswald, Andrew J. and Nattavudh Powdthavee. 2008. "Does happiness adapt? A longitudinal study of disability with implications for economists and judges." Journal of Public Economics, 92 (5-6): 1061-1077.

Oughton, Deborah, Ingrid Bay-Larsen and Gabriele Voigt. 2009. "Social, ethical, environmental and economic aspects of remediation." Radioactivity in the Environment, 14: 427-451.

Powdthavee, Nattavudh and Alois Stutzer. 2014. "Economic Approaches to Understanding Change in Happiness." In Sheldon, Kennon M. and Richard E. Lucas (eds.) Stability of Happiness, Amsterdam: Elsevier, forthcoming.

Rahu, M. 2003. "Health effects of the Chernobyl accident: fears, rumours and the truth." European Journal of Cancer, 39: 295-299.

Rubin, G. James, Richard Amlôt, Simon Wessely and Neil Greenberg. 2012. "Anxiety, distress and anger among British nationals in Japan following the Fukushima nuclear accident." British Journal of Psychiatry, 201:400-407.

Shigemura, Jun, Takeshi Tanigawa, Isao Saito and Soichiro Nomura. 2012. "Psychological Distress in Workers at the Fukushima Nuclear Power Plants." The Journal of the American Medical Association, 308(7): 667-669.

Slovic, Paul. 1987. "Perception of Risk.” Science, 236 (4799): 280-285.

Sovacool, Benjamin K. 2008. "The costs of failure: A preliminary assessment of major energy accidents, 1907-2007." Energy Policy, 36: 1802-1820.

State Statistics Committee of Ukraine. 2004. Statistical Yearbook of Ukraine 2003. Kiev, Ukraine.

Udovyk, Oleg. 2007. "Learning from Chernobyl: Past and present responses." in C. Mothersill et al. (eds.), Multiple Stressors: A Challenge for the Future: 449-453.

United Nations. 2001. "Optimizing the international effort to study, mitigate and minimize the consequences of the Chernobyl disaster." Report of the Secretary-General A/56/447. Retrieved 15 March 2013. URL: http://daccess-dds-ny.un.org/doc/UNDOC/ GEN/ N01/568 /09/PDF/N0156809.pdf?OpenElement 
United Nations. 2002. "The human consequences of the Chernobyl nuclear accident. A strategy for recovery." A Report Commissioned by UNDP and UNICEF with the support of UN-OCHA and WHO. Retrieved 15 March 2013. URL: http://chernobyl.undp.org/english/docs/strategy_for_recovery.pdf

UNSCEAR. 2000. "Exposures and effects of the Chernobyl accident." Annex J of Sources and Effects of Ionizing Radiation, Volume II. Vienna: United Nations.

UNSCEAR. 2008. "Health effects due to radiation from the Chernobyl accident." Annex D of Sources and Effects of Ionizing Radiation, Volume II. Vienna: United Nations.

U.S. National Academy of Sciences. 2006. Health risks from exposure to low levels of ionizing radiation. BEIR VII Report. National Research Council, U.S. National Academy of Sciences. Washington, DC: National Academy Press.

van Praag, Bernard M. S. and Barbara E. Baarsma. 2005. "Using happiness surveys to value intangibles: The case of airport noise." Economic Journal, 115 (500): 224-246.

Viinamäki, Heimo, Esko Kumpusalo, Markku Myllykangas, S. Salomaa, L. Kumpusalo, S. Kolmakov, I. Ilchenko, G. Zhukowsky and A. Nissinen. 1995. "The Chernobyl accident and mental well-being-A population study." Acta Psychiatrica Scandinavica, 91 (6): 396-401.

Wang, Philip S., Sergio Aguilar-Gaxiola, Jordi Alonso, Matthias C Angermeyer, Guilherme Borges, Evelyn J Bromet, Ronny Bruffaerts, Giovanni de Girolamo, Ron de Graaf, Oye Gureje, Josep Maria Haro, Elie G Karam, Ronald C Kessler, Viviane Kovess, Michael C Lane, Sing Lee, Daphna Levinson, Yutaka Ono, Maria Petukhova, José Posada-Villa, Soraya Seedat and J Elisabeth Wells. 2007. "Use of mental health services for anxiety, mood, and substance disorders in 17 countries in the WHO world mental health surveys." The Lancet, 370(9590): 841-850.

WHO. 2005. Mental health: facing the challenges, building solutions. Geneva: World Health Organization.

WHO. 2006. Health effects of the Chernobyl accident and special health care programmes: Report of the UN Chernobyl Forum Health Expert Group. Geneva: World Health Organization.

WHO. 2013. Investing in Mental Health: Evidence for Action. Geneva: World Health Organization.

WHO World Mental Health Survey Consortium. 2004. "Prevalence, Severity, and Unmet Need for Treatment of Mental Disorders in the World Health Organization World Mental Health Surveys." The Journal of the American Medical Association, 291 (21): 2581-2590.

Winkelmann, Liliana and Rainer Winkelmann. 1998. "Why are the unemployed so unhappy? Evidence from panel data." Economica, 65 (257): 1-15. 


\section{Online Appendix}

(not intended for publication) 


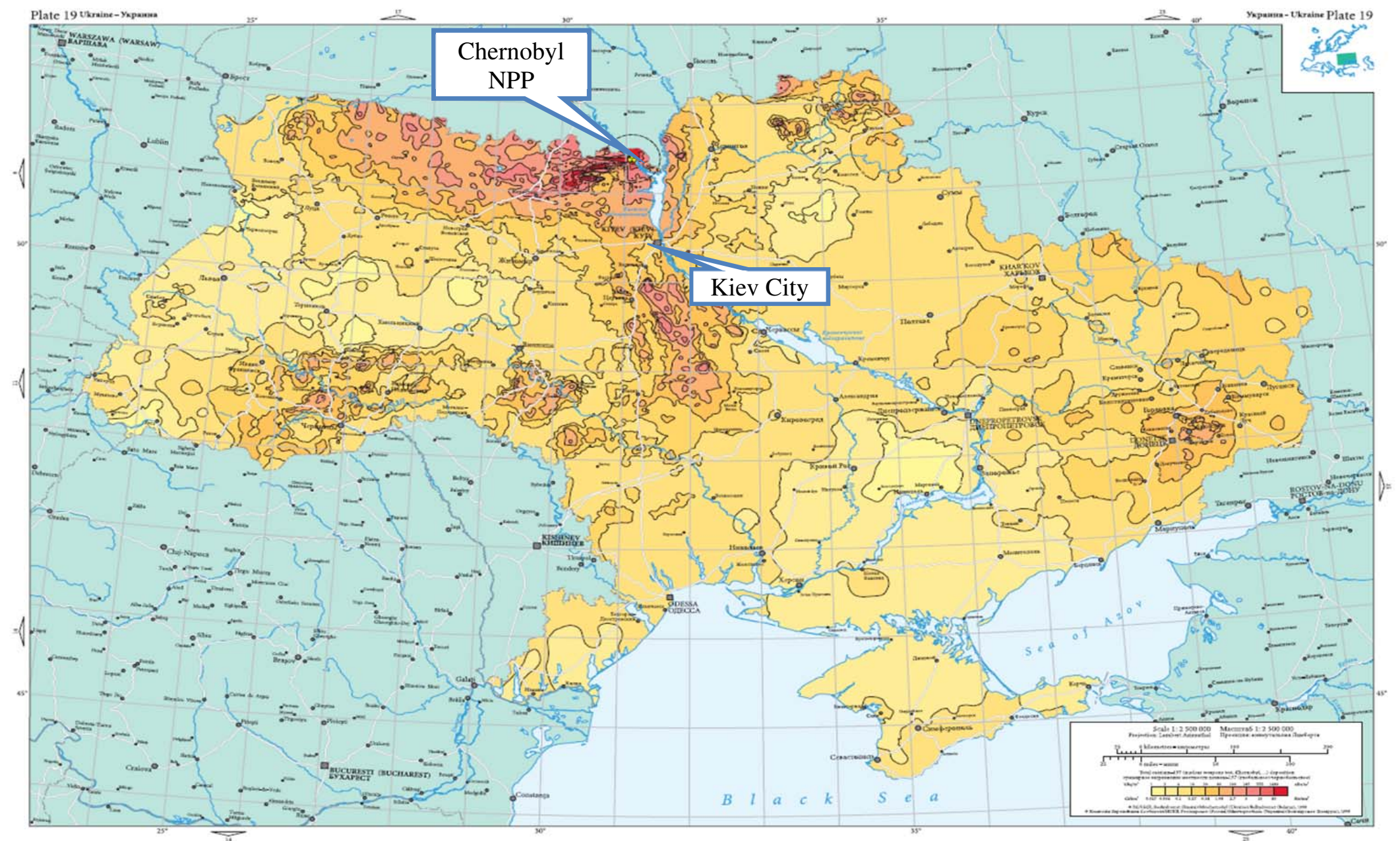

Fig. A-1: Regional variation of total caesium-137 deposition in 1986 in Ukraine

Source: European Commission (1998). Notes: Darker red areas indicate higher radiation levels. 
Table A-1: Structural differences between more and less affected regions, individual level regressions

\begin{tabular}{|c|c|c|c|c|c|}
\hline Dependent variable & $\begin{array}{c}(1) \\
\text { Inactive in } \\
1986 \\
\text { (Dummy) }\end{array}$ & $\begin{array}{c}(2) \\
\text { Higher } \\
\text { education in } \\
1986 \\
\text { (Dummy) }\end{array}$ & $\begin{array}{c}(3) \\
\text { Higher } \\
\text { education in } \\
1986 \\
\text { (Dummy) }\end{array}$ & $\begin{array}{c}(4) \\
\text { Nominal } \\
\text { wage in } 1986\end{array}$ & $\begin{array}{c}(5) \\
\text { Log wage } \\
\text { in } 1986\end{array}$ \\
\hline Radiation & $\begin{array}{l}-0.018 \\
(0.036)\end{array}$ & $\begin{array}{l}-0.014 \\
(0.028)\end{array}$ & $\begin{array}{l}-0.008 \\
(0.036)\end{array}$ & $\begin{array}{c}1.718 \\
(16.128)\end{array}$ & $\begin{array}{c}0.008 \\
(0.054)\end{array}$ \\
\hline $\begin{array}{l}\text { Observations } \\
\text { R-squared }\end{array}$ & & $\begin{array}{l}4,089 \\
0.065\end{array}$ & $\begin{array}{l}2,847 \\
0.146\end{array}$ & & $\begin{array}{l}2,847 \\
0.378\end{array}$ \\
\hline \multicolumn{6}{|c|}{$\begin{array}{l}\text { Note: Sample includes all individuals born between } 1929 \text { and } 1966 \text {. Of } 4,089 \text { respondents witl } \\
\text { complete personal information, } 3,780 \text { held a job in 1986, of which } 2,847 \text { provided complete jol } \\
\text { and wage information from their official work books (compulsory Soviet work registry) } \\
\text { Regressions (1) and (2) control for demographic characteristics (gender, age, marital status) an } \\
\text { place of residence. The remaining regressions also control for sector and industry of employmen } \\
\text { as well as firm size. Regressions (4) and (5) additionally control for education. Robust standarc } \\
\text { errors clustered at level of radiation region in parentheses. } * * * p<0.01, * * p<0.05, * p<0.1 \\
\text { Source: ULMS } 2003 \text {. }\end{array}$} \\
\hline
\end{tabular}


Table A-2: Structural differences between more and less affected regions, regional level regressions

\begin{tabular}{|c|c|c|c|c|c|c|c|c|c|c|}
\hline $\begin{array}{l}\text { Dependent } \\
\text { variable }\end{array}$ & \multicolumn{2}{|c|}{$\begin{array}{l}\text { Share higher } \\
\text { education } 1989\end{array}$} & \multicolumn{2}{|c|}{$\begin{array}{c}\text { Share no education } \\
1989\end{array}$} & \multicolumn{2}{|c|}{$\begin{array}{c}\text { Log wage } \\
1995\end{array}$} & \multicolumn{2}{|c|}{$\begin{array}{l}\text { Log wage growth } 1995- \\
2010\end{array}$} & \multicolumn{2}{|c|}{$\begin{array}{c}\text { Immigration rate } \\
1986-2003\end{array}$} \\
\hline Radiation & $\begin{array}{l}-0.016 \\
(0.017)\end{array}$ & & $\begin{array}{l}0.015 \\
(0.057)\end{array}$ & & $\begin{array}{l}-0.023 \\
(0.119)\end{array}$ & & $\begin{array}{l}-0.011 \\
(0.058\end{array}$ & & $\begin{array}{c}0.014 \\
(0.023)\end{array}$ & \\
\hline Affected region & & $\begin{array}{l}-0.003 \\
(0.003)\end{array}$ & & $\begin{array}{c}0.002 \\
(0.010)\end{array}$ & & $\begin{array}{l}-0.075 \\
(0.077)\end{array}$ & & $\begin{array}{c}0.007 \\
(0.027)\end{array}$ & & $\begin{array}{l}0.010 \\
(0.014)\end{array}$ \\
\hline $\begin{array}{l}\text { Observations } \\
\text { R-squared }\end{array}$ & $\begin{array}{c}816 \\
0.610\end{array}$ & $\begin{array}{c}816 \\
0.610\end{array}$ & $\begin{array}{c}816 \\
0.793\end{array}$ & $\begin{array}{c}816 \\
0.793\end{array}$ & $\begin{array}{c}26 \\
0.001\end{array}$ & $\begin{array}{c}26 \\
0.021\end{array}$ & $\begin{array}{c}26 \\
0.001\end{array}$ & $\begin{array}{c}26 \\
0.001\end{array}$ & $\begin{array}{c}26 \\
0.022\end{array}$ & $\begin{array}{c}26 \\
0.027\end{array}$ \\
\hline $\begin{array}{l}\text { Note: Regression } \\
\text { settlement type, } \\
\text { dummy variable } \\
\text { oblast). Robust s } \\
2003 \text {. }\end{array}$ & rd erro & $\begin{array}{l}\text { se oblas } \\
\text { total } p \\
\text { ost affec } \\
\text { in paren }\end{array}$ & $\begin{array}{l}\text { areas i } \\
\text { ses. } * *:\end{array}$ & 0.01 , * & $x$ settles & t (rural & an) $\times$ ag & Rovensl & $\begin{array}{l}\text { d contro } \\
\text { Affecte } \\
\text { blast, C }\end{array}$ & $\begin{array}{l}\text { r gender } \\
\text { gion is a } \\
\text { govskaya } \\
0 \text {; ULMS }\end{array}$ \\
\hline
\end{tabular}


Table A-3: Variable definition (ULMS survey)

\begin{tabular}{|c|c|}
\hline Variable name & Variable definition \\
\hline \multicolumn{2}{|l|}{ Dependent variable } \\
\hline Life satisfaction & $\begin{array}{l}\text { Standardized version of the survey question: To what extent } \\
\text { are you satisfied with your life in general at the present } \\
\text { time? Answer options: } 1 \text { Fully dissatisfied/ } 2 \text { Rather } \\
\text { dissatisfied/ } 3 \text { Neither satisfied, nor dissatisfied/4 Rather } \\
\text { satisfied/ } 5 \text { Fully satisfied (mean }=0 \text {, variance =1) }\end{array}$ \\
\hline Depression or chronic anxiety & $\begin{array}{l}\text { Survey question: "Have you been diagnosed by a physician } \\
\text { with depression or chronic anxiety for more than } 6 \\
\text { months?" }\end{array}$ \\
\hline Transfer dependency & $\begin{array}{l}\text { Fraction of total household income received in the form of } \\
\text { government transfers and benefits }\end{array}$ \\
\hline Subjective working probability & $\begin{array}{l}\text { Survey question: "What are the chances that you will work } \\
\text { beyond official retirement age?" (0-100\%) }\end{array}$ \\
\hline Subjective survival probability & $\begin{array}{l}\text { Survey question: "What are the chances that you will live } \\
\text { to be age }[X] \text { and older?" }(0-100 \%)\end{array}$ \\
\hline Radiation measures & $\begin{array}{l}\text { Source: “20 Years After Chernobyl Catastrophe. Future } \\
\text { Outlook: National Report of Ukraine,” Tables 3.3.7 and } \\
\text { 3.3.9 (Baloga, Kholosha, and Evdin 2006, pages 45-48). }\end{array}$ \\
\hline Radiation & $\begin{array}{l}\text { Average total (internal + external) exposure doses, } \\
\text { accumulated in 1986, mSv, expressed in units of natural } \\
\text { background radiation per year. The dose equivalent of } \\
\text { ionizing radiation measures the biological effects in the } \\
\text { human organisms (in sievert; mSv - millisievert). }\end{array}$ \\
\hline Iodine-131 & $\begin{array}{l}\text { Average thyroid doses due to fallout of iodine-131 (in } \\
\text { milligray, mGy), for males and females aged } 1-18 \text { in } 1986 \text {. } \\
\text { The deposited energy is measured in } \log (0.1+\text { iodine- } 131 \\
\text { mGy). }\end{array}$ \\
\hline \multicolumn{2}{|l|}{$\begin{array}{l}\text { Sociodemographic and household } \\
\text { characteristics }\end{array}$} \\
\hline Age & Age, based on birth year, month and day \\
\hline Male & $=1$, if male $;=0$ otherwise \\
\hline \multicolumn{2}{|l|}{ Marital status } \\
\hline Single & $=1$, if single \\
\hline Married & $=1$, if married (lives in registered or unregistered marriage) \\
\hline Divorced & $=1$, if separated or divorced \\
\hline Widowed & $=1$, if widowed \\
\hline \multicolumn{2}{|l|}{ Education } \\
\hline Years of education & Adjusted years of completed education \\
\hline \multicolumn{2}{|l|}{ Employment status } \\
\hline $\begin{array}{l}\text { Employed, self-employed, } \\
\text { pensioner and inactive }\end{array}$ & Four dummy variables for employment status \\
\hline
\end{tabular}




\begin{tabular}{ll}
\hline Health, risky behavior and traits & $\begin{array}{l}\text { = } 1, \text { if person has at least one of seven chronic diseases } \\
\text { (self-reported): heart disease, illness of the lungs, liver } \\
\text { disease, kidney disease, gastrointestinal disease, spinal } \\
\text { problems, other chronic illnesses }\end{array}$ \\
\hline Height & $=1$, height of respondent in cm \\
\hline Smoking & $=1$, if person reports to currently smoke \\
\hline Drinking & $\begin{array}{l}\text { Number of household members, as measured in the } \\
\text { household roster }\end{array}$ \\
\hline Household variables & $\begin{array}{l}\text { Total living space of household in sqm. divided by number } \\
\text { of household members }\end{array}$ \\
\hline Household size & $\begin{array}{l}\text { Household income sums up all income sources: Labor } \\
\text { incomes, incomes from self-employment and irregular } \\
\text { employment, governmental transfers, inter-household } \\
\text { transfers, income from renting out land, flats etc., income } \\
\text { from financial investments }\end{array}$ \\
\hline Log of household income &
\end{tabular}

\begin{tabular}{|c|c|}
\hline Other controls & \\
\hline Oblast & $\begin{array}{l}\text { A set of dummy variables for each of the } 26 \text { oblasts of } \\
\text { Ukraine }\end{array}$ \\
\hline Village & $\begin{array}{l}=1, \text { if current place of living is in a rural settlement } \\
\text { (omitted category) }\end{array}$ \\
\hline Town & $\begin{array}{l}=1 \text {, if current place of living has status of small town or } \\
\text { town with less than } 100,000 \text { inhabitants }\end{array}$ \\
\hline City & $\begin{array}{l}=1 \text {, if population size of current place of living is } 100,000 \\
\text { or more }\end{array}$ \\
\hline Month of interview & Month of interview fixed effects \\
\hline Year 2004, year 2007 & $\begin{array}{l}\text { Year fixed effects for survey years (omitted category: year } \\
2003 \text { ) }\end{array}$ \\
\hline
\end{tabular}


Table A-4: Descriptive statistics (ULMS 2003-2007)

\begin{tabular}{|c|c|c|c|c|}
\hline Variable & Mean & Min. & Max. & $\begin{array}{c}\text { Number of } \\
\text { observations }\end{array}$ \\
\hline \multicolumn{5}{|l|}{ Dependent variables } \\
\hline Life satisfaction (Std. deviation: 1.16) & 2.59 & 1 & 5 & 11922 \\
\hline Unhappy & 0.21 & 0 & 1 & 11922 \\
\hline Subjective survival probability to target age & 53.9 & 0 & 100 & 1958 \\
\hline Transfer dependency & 0.09 & 0 & 1 & 7985 \\
\hline Business & 0.06 & 0 & 1 & 7985 \\
\hline Subjective working probability & 0.51 & 0 & 100 & 2063 \\
\hline Favor central economy & 0.33 & 0 & 1 & 9588 \\
\hline \multicolumn{5}{|l|}{ Radiation measure } \\
\hline Radiation (natural background radiation units) & 0.47 & 0 & 1.1 & 11922 \\
\hline Log thyroid dose & 2.06 & -9.21 & 4.54 & 11922 \\
\hline \multicolumn{5}{|l|}{ Demographic and health controls } \\
\hline Male & 0.40 & 0 & 1 & 11922 \\
\hline Age & 46.3 & 17 & 75 & 11922 \\
\hline Height & 167.7 & 120 & 200 & 11922 \\
\hline Chronic disease & 0.57 & 0 & 1 & 11922 \\
\hline Smoking & 0.28 & 0 & 1 & 11922 \\
\hline Drink alcohol & 0.46 & 0 & 1 & 11922 \\
\hline \multicolumn{5}{|l|}{ Marital status, education and work status } \\
\hline Single & 0.11 & 0 & 1 & 11922 \\
\hline Married & 0.71 & 0 & 1 & 11922 \\
\hline Widowed & 0.09 & 0 & 1 & 11922 \\
\hline Separated & 0.09 & 0 & 1 & 11922 \\
\hline Years of schooling & 11.9 & 4 & 18 & 11922 \\
\hline Working & 0.54 & 0 & 1 & 11922 \\
\hline Unemployed & 0.07 & 0 & 1 & 11922 \\
\hline Pensioner & 0.24 & 0 & 1 & 11922 \\
\hline Inactive & 0.15 & 0 & 1 & 11922 \\
\hline \multicolumn{5}{|l|}{ Household characteristics, wealth and settlement } \\
\hline Household size & 3.30 & 1 & 13 & 11922 \\
\hline Log household income & 6.50 & 0 & 9.40 & 11922 \\
\hline Housing space per capita (sqm.) & 23.2 & 5.3 & 152.0 & 11922 \\
\hline Village & 0.34 & 0 & 1 & 11922 \\
\hline Town & 0.26 & 0 & 1 & 11922 \\
\hline City & 0.40 & 0 & 1 & 11922 \\
\hline
\end{tabular}

Source: ULMS 2003-2007; own calculations. 
Table A-5: OLS regressions of subjective well-being, various age controls
$(1)$
(2)
(3)
(4)
(5)
(6)

Dependent variable Subjective well-being

Radiation

$-0.166 * * * \quad-0.192 * * *$

$-0.200 * * *$

$-0.172 * * *$

$-0.172 * * * \quad-0.172 * * *$

Age

$-0.011^{* * *}$

(0.051)

(0.049)

(0.056)

(0.056)

(0.056)

Age squared

(0.001)

$(0.007)$

$-0.163 * * *$

(0.020)

$0.001 * * * \quad 0.003 * * *$

Age cubic

(0.000)

(0.000)

$-0.000 * * *$

(0.000)

$\log ($ Age $)$

(0.043)

$\log ($ Age $)$ squared

$-0.248 * * *$

(0.021)

Log(Age) cubic

$\begin{array}{ccc} & (0.021) & \\ & & -0.166^{* * * *} \\ & & (0.014) \\ \checkmark & \checkmark & \checkmark \\ 11,922 & 11,922 & 11,922 \\ 0.189 & 0.189 & 0.189\end{array}$

Full controls

Observations

11,922

11,922

11,922

0.189

0.189

0.189

Notes: Full controls see Table 1. Robust standard errors clustered at the radiation region in parentheses. $* * * p<0.01$,

$* * \mathrm{p}<0.05, * \mathrm{p}<0.1$. Source: ULMS 2003-2007; own calculations.

Table A-6: Chernobyl effect by subgroups

(1) (2)

Dependent variable

Subjective well-being

\begin{tabular}{lclc}
\hline Subgroup effects & & & \\
Radiation female $\left(\hat{\beta}_{1}\right)$ & $-0.244^{* * *}$ & Radiation young $\left(\hat{\beta}_{1}\right)$ & $-0.237 * * *$ \\
& $(0.041)$ & & $(0.070)$ \\
Radiation male $\left(\hat{\beta}_{1}+\hat{\beta}_{2}+\hat{\beta}_{3}\right)$ & $-0.158^{* * *}$ & Radiation old $\left(\hat{\beta}_{1}+\hat{\beta}_{2}+\hat{\beta}_{3}\right)$ & $-0.346^{* * *}$ \\
& $(0.067)$ & & $(0.154)$ \\
\hline Marginal effects & & & -0.209 \\
Male $\left(\hat{\beta}_{2}\right)$ & -0.024 & Older $\left(\hat{\beta}_{2}\right)$ & $(0.150)$ \\
& $(0.047)$ & & 0.100 \\
Male $\times$ Radiation $\left(\hat{\beta}_{3}\right)$ & 0.110 & Older $\times$ Radiation $\left(\hat{\beta}_{3}\right)$ & $(0.106)$ \\
& $(0.088)$ & & 11,922 \\
Observations & 11,922 & & 0.200 \\
R-squared & 0.200 & & \\
\hline
\end{tabular}

Notes: Older defined as age 46 (median age of sample) to 75 . Full controls see Table 1. Robust standard errors clustered at the radiation region in parentheses. $* * * \mathrm{p}<0.01$, ** $\mathrm{p}<0.05$, * $\mathrm{p}<0.1$. Source: ULMS 2003-2007; own calculations. 
Table A-7: Alternative specifications

\begin{tabular}{|c|c|c|c|c|c|c|c|}
\hline Estimation method & $\begin{array}{l}(1) \\
\text { OLS }\end{array}$ & $\begin{array}{c}\text { (2) } \\
\text { OLS } \\
\text { standardized }\end{array}$ & $\begin{array}{c}(3) \\
\text { Ordered } \\
\text { Probit }\end{array}$ & $\begin{array}{c}(4) \\
\text { Interval } \\
\text { regression }\end{array}$ & $\begin{array}{c}\text { (5) } \\
\text { GLS-RE }\end{array}$ & $\begin{array}{c}(6) \\
\mathbf{L P M}\end{array}$ & $\begin{array}{c}(7) \\
\text { Probit } \\
\text { (marginal } \\
\text { effects) } \\
\end{array}$ \\
\hline Dependent variables & \multicolumn{4}{|c|}{ Life satisfaction (1-5) } & & \multicolumn{2}{|c|}{ Being unhappy $(0 / 1)$} \\
\hline Radiation & $\begin{array}{c}-0.196 * * * \\
(0.052)\end{array}$ & $\begin{array}{c}-0.044 * * * \\
(0.012)\end{array}$ & $\begin{array}{c}-0.246 * * * \\
(0.065)\end{array}$ & $\begin{array}{c}-0.234 * * * \\
(0.088)\end{array}$ & $\begin{array}{c}-0.180 * * * \\
(0.052)\end{array}$ & $\begin{array}{c}0.097 * * * \\
(0.027)\end{array}$ & $\begin{array}{c}0.102 * * * \\
(0.028)\end{array}$ \\
\hline Observations & 11,922 & 11,922 & 11,922 & 11,922 & 11,922 & 11,922 & 11,919 \\
\hline R-squared & 0.200 & 0.200 & & & 0.200 & 0.156 & \\
\hline Pseudo R-squared & & & 0.075 & & & & 0.166 \\
\hline Log pseudolikelihood & & & $-16,707$ & $-17,621$ & & & $-5,237$ \\
\hline
\end{tabular}


Table A-8: Life satisfaction regressions for single years

\begin{tabular}{|c|c|c|c|c|}
\hline Sample & $\begin{array}{c}(1) \\
\text { Pooled }\end{array}$ & $\begin{array}{c}(2) \\
\mathbf{2 0 0 3}\end{array}$ & $\begin{array}{c}(3) \\
2004\end{array}$ & $\begin{array}{c}(4) \\
2007\end{array}$ \\
\hline Dependent variable & \multicolumn{4}{|c|}{ Life satisfaction } \\
\hline Unbalanced panel & & & & \\
\hline Radiation & $\begin{array}{c}-0.196 * * * \\
(0.052)\end{array}$ & $\begin{array}{c}-0.315^{* *} \\
(0.114)\end{array}$ & $\begin{array}{c}-0.174 * * \\
(0.079)\end{array}$ & $\begin{array}{c}-0.127 * \\
(0.066)\end{array}$ \\
\hline Observations & 11,922 & 3,894 & 3,666 & 4,362 \\
\hline R-squared & 0.200 & 0.188 & 0.236 & 0.155 \\
\hline \multicolumn{5}{|l|}{ Balanced panel } \\
\hline Radiation & $\begin{array}{c}-0.308 * * * \\
(0.061)\end{array}$ & $\begin{array}{c}-0.358 * * * \\
(0.099)\end{array}$ & $\begin{array}{c}-0.365 * * * \\
(0.078)\end{array}$ & $\begin{array}{c}-0.268 * * * \\
(0.096)\end{array}$ \\
\hline Observations & 8,052 & 2,684 & 2,684 & 2,684 \\
\hline R-squared & 0.198 & 0.185 & 0.236 & 0.172 \\
\hline
\end{tabular}

Notes: Pooled OLS regressions. All regressions include full set of controls. Robust standard errors clustered at the radiation region in parentheses. $* * * p<0.01, * *$ $\mathrm{p}<0.05, * \mathrm{p}<0.1$. Source: ULMS 2003-2007; own calculations. 
Table A-9: Robustness check: separate omission of most affected regions

\begin{tabular}{|c|c|c|c|c|c|c|c|}
\hline & $\begin{array}{c}(1) \\
\text { Without } \\
\text { Kiev } \\
\text { oblast }\end{array}$ & $\begin{array}{c}(2) \\
\text { Without } \\
\text { Zhytomyr } \\
\text { oblast }\end{array}$ & $\begin{array}{c}(3) \\
\text { Without } \\
\text { Rivne } \\
\text { oblast }\end{array}$ & $\begin{array}{c}(4) \\
\text { Without } \\
\text { Cherkasy } \\
\text { oblast }\end{array}$ & $\begin{array}{c}(5) \\
\text { Without } \\
\text { Chernihiv } \\
\text { oblast }\end{array}$ & $\begin{array}{c}(6) \\
\text { Without } \\
\text { Vinnitsky } \\
\text { oblast }\end{array}$ & $\begin{array}{c}(7) \\
\text { Without } \\
\text { Kiev city }\end{array}$ \\
\hline Dependent variable & \multicolumn{7}{|c|}{ Life satisfaction } \\
\hline Radiation & $\begin{array}{c}-0.187 * * * \\
(0.051)\end{array}$ & $\begin{array}{c}-0.225 * * * \\
(0.049)\end{array}$ & $\begin{array}{c}-0.194 * * * \\
(0.052)\end{array}$ & $\begin{array}{c}-0.254 * * * \\
(0.056)\end{array}$ & $\begin{array}{c}-0.187 * * * \\
(0.052)\end{array}$ & $\begin{array}{c}-0.190 * * * \\
(0.053)\end{array}$ & $\begin{array}{c}-0.199 * * * \\
(0.066)\end{array}$ \\
\hline $\begin{array}{l}\text { Demographic } \\
\text { controls }\end{array}$ & $\checkmark$ & $\checkmark$ & $\checkmark$ & $\checkmark$ & $\checkmark$ & $\checkmark$ & $\checkmark$ \\
\hline Household controls & $\checkmark$ & $\checkmark$ & $\checkmark$ & $\checkmark$ & $\checkmark$ & $\checkmark$ & $\checkmark$ \\
\hline Health \& traits & $\checkmark$ & $\checkmark$ & $\checkmark$ & $\checkmark$ & $\checkmark$ & $\checkmark$ & $\checkmark$ \\
\hline Observations & 11,576 & 11,609 & 11,670 & 11,585 & 11,540 & 11,374 & 11,402 \\
\hline R-squared & 0.201 & 0.200 & 0.195 & 0.202 & 0.195 & 0.208 & 0.200 \\
\hline
\end{tabular}


Table A-10: Controlling for proximity to a nuclear power plant

\begin{tabular}{|c|c|c|c|c|c|}
\hline Dependent variable & (1) & (2) & $\begin{array}{c}(3) \\
\text { Life satisfaction }\end{array}$ & (4) & (5) \\
\hline Radiation & $\begin{array}{c}-0.196 * * * \\
(0.052)\end{array}$ & $\begin{array}{c}-0.198 * * \\
(0.072)\end{array}$ & $\begin{array}{c}-0.211 * * * \\
(0.070)\end{array}$ & $\begin{array}{c}-0.196 * * * \\
(0.052)\end{array}$ & $\begin{array}{c}-0.183 * * * \\
(0.054)\end{array}$ \\
\hline Living close to a nuclear power plant 1986 & & $\begin{array}{c}0.005 \\
(0.122)\end{array}$ & $\begin{array}{l}-0.101 \\
(0.238)\end{array}$ & & \\
\hline Living close to a nuclear power plant today & & & & $\begin{array}{c}0.031 \\
(0.065)\end{array}$ & $\begin{array}{c}0.095 \\
(0.075)\end{array}$ \\
\hline Radiation $\times$ Living close to a nuclear power plant 1986 & & & $\begin{array}{c}0.161 \\
(0.259)\end{array}$ & & \\
\hline Radiation $\times$ Living close to a nuclear power plant today & & & & & $\begin{array}{l}-0.214 \\
(0.130)\end{array}$ \\
\hline Observations & 11,922 & 11,922 & 11,922 & 11,922 & 11,922 \\
\hline R-squared & 0.200 & 0.200 & 0.200 & 0.200 & 0.200 \\
\hline
\end{tabular}

Notes: Pooled OLS regressions. All regressions include full set of controls. Robust standard errors clustered at the radiation region in parentheses. Living close to a nuclear power plant is defined as residing in a region in which a nuclear power plant is located (Khmelnytsky (opened 1987), Rivne, South Ukraine, Zaporizhzhia

and Chernobyl (out of service today)). $* * * \quad \mathrm{p}<0.01, \quad * * \quad \mathrm{p}<0.05, \quad * \quad \mathrm{p}<0.1$. Source: ULMS 2003-2007; own calculations. 